Article

\title{
Marinopyrrole Derivatives as Potential Antibiotic Agents against Methicillin-Resistant Staphylococcus aureus (II)
}

\author{
Chunwei Cheng ${ }^{1}$, Yan Liu ${ }^{2}$, Hao Song ${ }^{1}$, Lili Pan ${ }^{1}$, Jerry $\mathrm{Li}^{2}$, Yong Qin ${ }^{1,3, *}$ and \\ Rongshi Li ${ }^{2,4, *}$
}

1 Key Laboratory of Drug Targeting and Drug Delivery Systems of the Ministry of Education and State Key Laboratory of Biotherapy, Department of Medicinal Natural Products, West China School of Pharmacy, Sichuan University, Chengdu 610041, China;

E-Mails: chengchunwei666@163.com (C.C.); haoright@163.com (H.S.); pande179@163.com (L.P.)

2 Chemical Biology \& Molecular Medicine Program, Department of Drug Discovery, H. Lee Moffitt Cancer Center and Research Institute, 12902 Magnolia Drive, Tampa, FL 33612, USA;

E-Mails: yan.liu@moffitt.org (Y.L.); jerry.li.91@berkeley.edu (J.L.)

3 The Innovative Drug Research Centre, Chongqing University, Chongqing 400000, China

4 Department of Oncologic Sciences, Morsani College of Medicine, University of South Florida, 12901 Bruce B. Downs, Tampa, FL 33612, USA

* Authors to whom correspondence should be addressed; E-Mails: rongshi.li@moffitt.org (R.L.); yongqin@scu.edu.cn (Y.Q.); Tel.: +1-813-745-6485 (R.L.); Fax: +1-813-745-6875 (R.L.); Tel./Fax: +86-28-8550-3842 (Y.Q.).

Received: 13 June 2013; in revised form: 17 July 2013 / Accepted: 24 July 2013 /

Published: 15 August 2013

\begin{abstract}
Methicillin-resistant Staphylococcus aureus (MRSA) continues to be a major problem, causing severe and intractable infections worldwide. MRSA is resistant to all beta-lactam antibiotics, and alternative treatments are limited. A very limited number of new antibiotics have been discovered over the last half-century, novel agents for the treatment of MRSA infections are urgently needed. Marinopyrrole A was reported to show antibiotic activity against MRSA in 2008. After we reported the first total synthesis of $( \pm)$-marinopyrrole A, we designed and synthesized a series of marinopyrrole derivatives. Our structure activity relationship (SAR) studies of these novel derivatives against a panel of Gram-positive pathogens in antibacterial assays have revealed that a para-trifluoromethyl analog (33) of marinopyrrole A is $\geq 63-, 8$-, and 4-fold more potent than vancomycin against methicillin-resistant Staphylococcus epidermidis (MRSE),
\end{abstract}


methicillin-susceptible Staphylococcus aureus (MSSA) and MRSA, respectively. The results provide valuable information in the search for new-generation antibiotics.

Keywords: antibiotics; marinopyrroles; MRSA; MRSE; MSSA; SAR

\begin{abstract}
Abbreviations
ADME, absorption, distribution, metabolism and excretion; DCM, dichloromethane; DIEA, diisopropylethylamine; DMF, dimethylformamide; DMSO, dimethyl sulfoxide; EtOAc, ethyl acetate; ESI, electrospray ionization; IBX, 2-iodoxybenzoic acid; $\mathrm{KBr}$, potassium bromide; KF, potassium fluoride; MeCN, acetonitrile; $\mathrm{MeOH}$, methyl alcohol; NCS, N-chlorosuccinimide; TBAF, tetrabutylammonium fluoride; TBDMS, $t$-butyldimethylsilyl; TBDMSCl, $t$-butyldimethylsilyl chloride; Tf, trifluoromethanesulfonyl; THF, tetrahydrofuran; WHO, World Health Organization.
\end{abstract}

\title{
1. Introduction
}

The global crisis of antibiotic resistance has spread rapidly over the past several decades. Methicillin-resistant Staphylococcus aureus (MRSA) infections have reached epidemic proportions in many countries [1] and represent the most common cause of skin and soft tissue infections in the United States [2]. Both hospital-associated and community-associated MRSA can exhibit broad resistance to multiple classes of antibiotics [1-5]. Hospital-associated MRSA infections are common among healthcare facilities and are resistant to many antibiotics. However, community-associated MRSA strains are highly virulent and even infect healthy individuals; the incidence of these infections has skyrocketed in the past decade. The relative abandonment of antibiotic discovery and development by the pharmaceutical industry has opened opportunities for academic researchers to discover new antibiotics to treat these increasingly problematic infections. Except for the addition of the oxazolidinone linezolid [6] in 2000, the lipopeptide daptomycin [7] in 2003, and the US Food and Drug Administration's recent approval of ceftaroline [8], a very limited number of new antibiotics have been marketed over the past half-century. Only two new classes of anti-MRSA drugs have been approved in the last 40 years. Clearly, novel agents for the treatment of MRSA infections are urgently needed [9].

Marinopyrroles were first reported to show antibiotic activity against MRSA in 2008 by the Fenical group [10]. Due to their novel class of molecular structures and promising biological properties, marinopyrroles have attracted considerable attention [11-19]. We reported the first total synthesis of $( \pm)$-marinopyrrole A, along with 12 derivatives in early 2010 [12]. Synthesis of ( \pm )-marinopyrrole A via an intermolecular Ullman coupling reaction as a key step to form bispyrrole system was published by Kanakis and Sarli five months later [13]. In 2011, the Nicolaou group published a new five-step method to access marinopyrrole derivatives, $(+)$ - and (-)-atropisomer after a chiral separation of $( \pm)$-marinopyrrole A using HPLC, as well as their antibiotic activities against MRSA [14]. Recently, the Moore group published biosynthesis of marinopyrrole A via an $N, C$-bipyrrole homocoupling catalyzed by two flavin-dependent halogenases [17]. Most recently, racemic marinopyrrole B was 
reported by total synthesis from the Clive group [18]. During the preparation of this manuscript, a review of the marinopyrroles appeared [19]. We have reported synthesis of a novel series of "non-symmetrical" marinopyrrole derivatives and their antibiotic activities [15]. These derivatives demonstrated superior antibiotic activities to that of the parent marinopyrrole A against MRSA [15]. Last year, we published optimization of the key step to avoid the formation of oxazepine byproduct [16].

\section{Results and Discussion}

\subsection{Synthesis of Marinopyrrole Derivatives}

In 2010, we reported the first total synthesis of $( \pm)$-marinopyrrole A (1) and a dozen "symmetrical" derivatives [12], which bear the same substituents with the same substitution patterns on both rings A and $\mathrm{B}$ attached to the carbonyl groups as shown in Scheme 1. A nine-step synthesis was required to access $\mathbf{1}$, in which a limitation was the formation of oxazepine byproduct $\mathbf{5}$. Recently, we optimized the synthesis of marinopyrrole derivatives [16] to circumvent the chemistry issues that we reported in our first publication [12]. As shown in Scheme 1, the formation of oxazepine 5 after a Grignard addition to aldehyde 3, followed by work-up under weakly acidic conditions (AcOH) cannot be avoided due to reactive diol intermediate 4. Oxazepine 5 is readily formed even on silica gel with attempted purification by column chromatography. Although this issue was avoided by direct oxidation of the crude diol 4 to ketone [12], the reproducibility suffered and the yields varied from batch to batch. The key to solving such chemistry issues was sequential introduction of rings A and B via mono-protection of aldehyde $\mathbf{3}$, as we reported earlier [16]. In this paper, we report alternative approaches to accomplishing the sequential introduction of rings A and B. As shown in Scheme 2, selective oxidation of diol 6 was achieved by IBX in DMSO in $72 \%$ yield. Protection of 7 with TBDMS afforded intermediate $\mathbf{8}$ in 70\% yield. Addition of $\mathbf{9}$ to aldehyde $\mathbf{8}$ in $90 \%$ yield followed by oxidation of the resulting alcohol 10 by IBX in DMSO afforded ketone 11 in $82 \%$ yield. Compound 12 was obtained by removal of the silyl-protecting group in $\mathbf{1 1}$ by TBAF in $95 \%$ yield. Oxidation of $\mathbf{1 2}$ by IBX in DMSO furnished the aldehyde 13 in $96 \%$ yield. Addition of 9 to 13 furnished 14 in $85 \%$ yield, which was subjected to oxidation by IBX in DMSO affording diketone 15 in $90 \%$ yield. Double alkylation on both aldehyde and ketone in 13 was observed, generating both desired product 14 in $85 \%$ and oxazepine byproduct $\mathbf{1 4 A}$ in 5\% yield (Figure 1 and Experimental Section). It is worthwhile to note that this new synthetic strategy is versatile. This synthetic route has paved the way to access not only the "symmetrical" marinopyrroles but also "non-symmetrical" congeners when two different Grignard or organic lithium reagents are used. Deprotection of diketone $\mathbf{1 5}$ by hydrogenolysis furnished 16. Removal of tosyl protecting group by $\mathrm{KOH}$ generated $\mathbf{1 7}$, which was then converted to 18 by chlorination with NCS. The final symmetrical marinopyrrole derivative $\mathbf{1 9}$ was obtained after demethylation using $\mathrm{BBr}_{3} / \mathrm{DCM}$ [12]. With intermediate 16 as a starting material (Scheme 3), the two phenolic hydroxyl groups were activated by trifluoromethanesulfonic anhydride in the presence of DIEA in anhydrous acetonitrile. Tetrachlorination of $\mathbf{2 0}$ with NCS in DMF furnished 21 in $35 \%$ yield. Demethylation of 21 with $\mathrm{BBr}_{3}$ followed by removal of the tosyl-protecting group afforded an intermediate 23. Compound $\mathbf{2 4}$ was obtained after removal of $\mathrm{Tf}$ with $\mathrm{KF}$ in $75 \%$ yield. 
Scheme 1. Synthesis of marinopyrrole A.

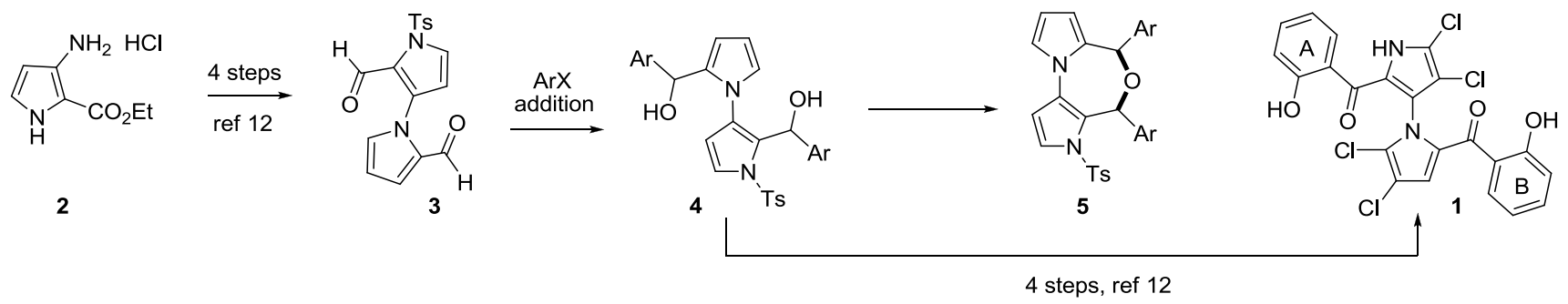

Scheme 2. General route for the synthesis of marinopyrrole derivatives $\mathbf{1 8}$ and $\mathbf{1 9 .}$
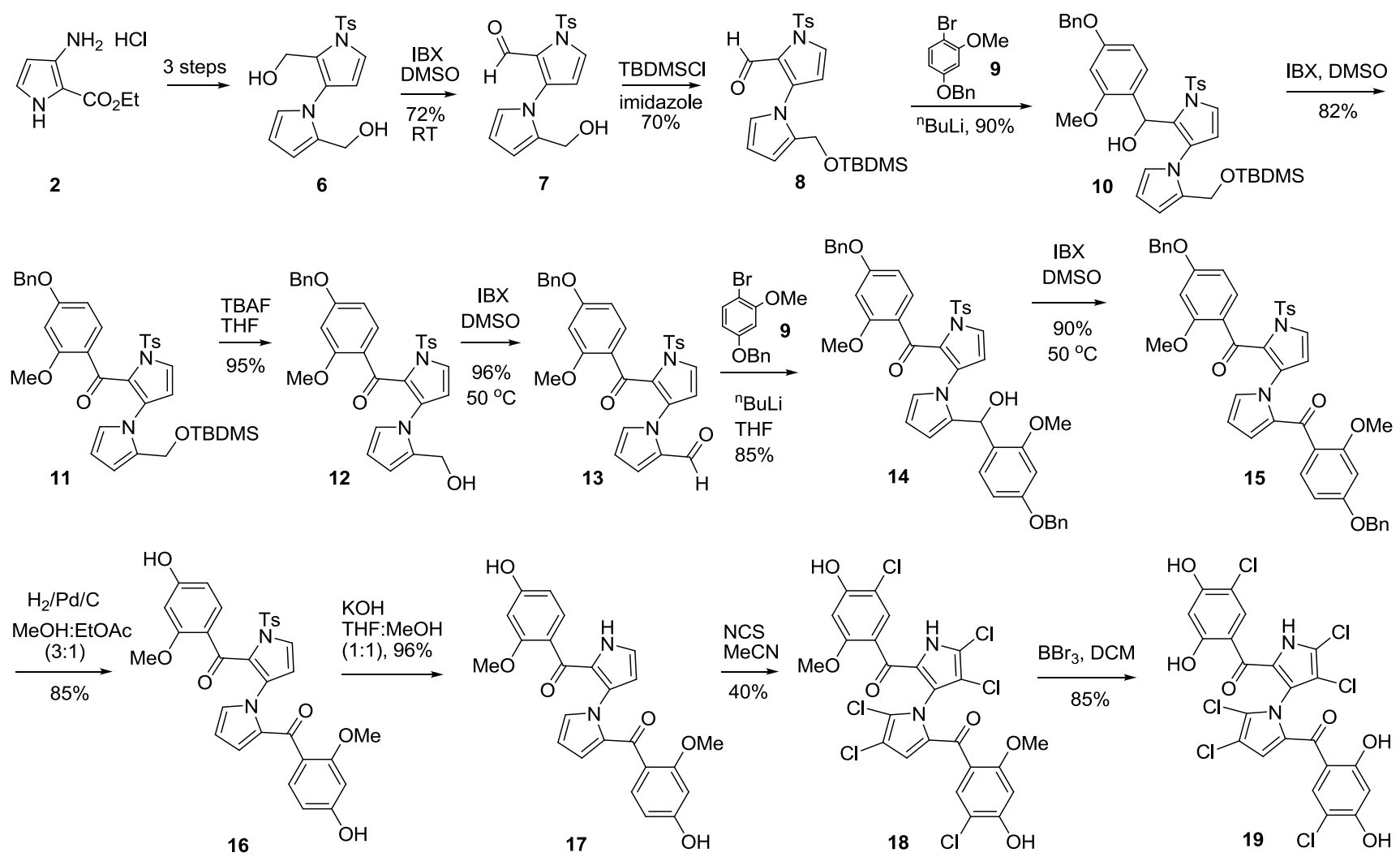

Figure 1. Dialkylation byproduct.

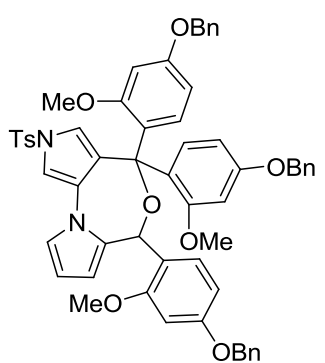

14A

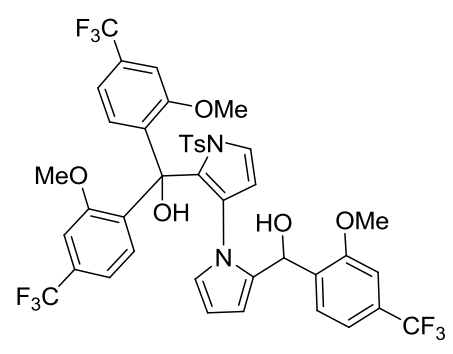

29A 
Scheme 3. Synthesis of marinopyrrole derivative 24.
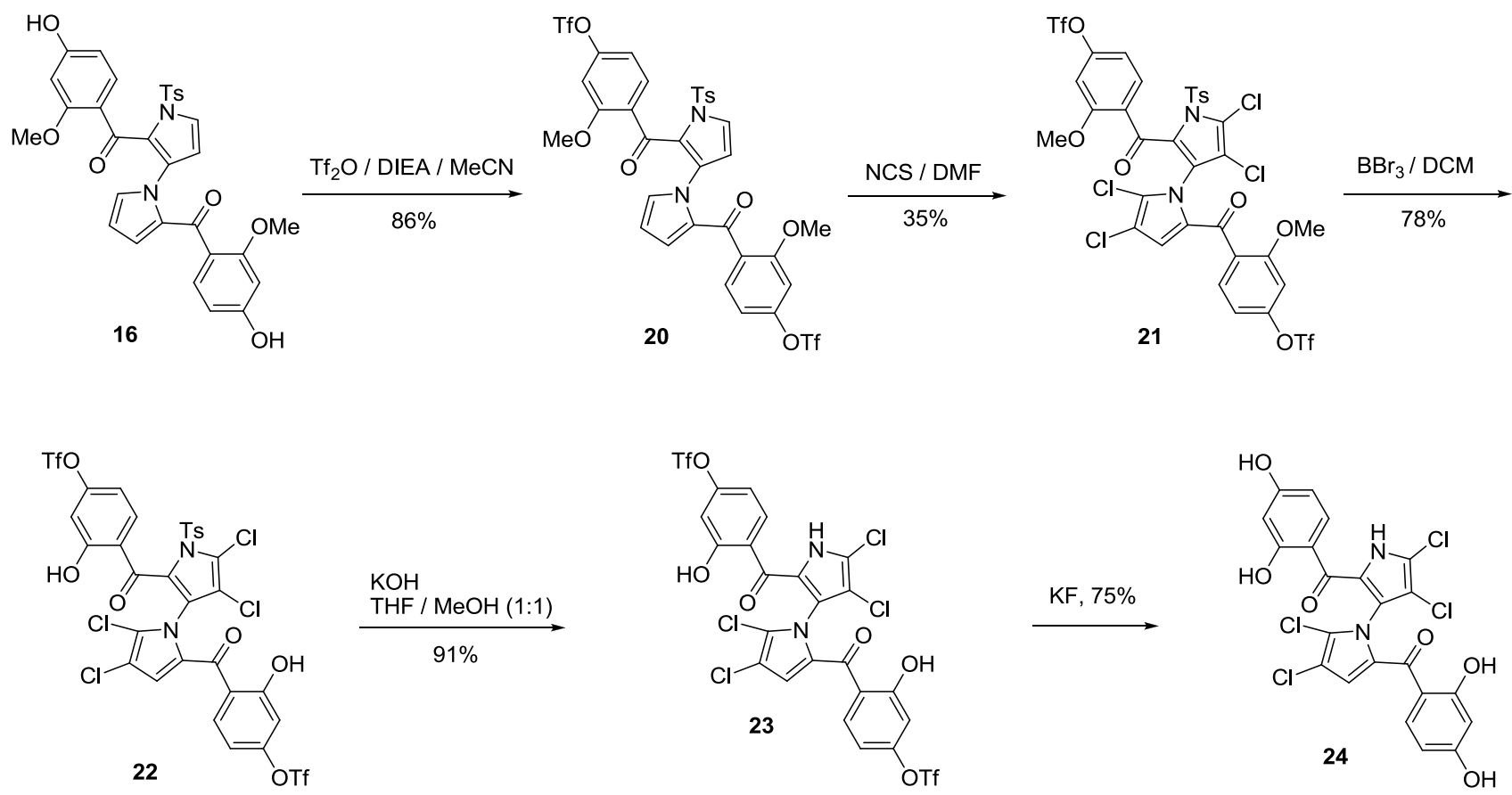

Scheme 4. Synthesis of marinopyrrole derivative 33.
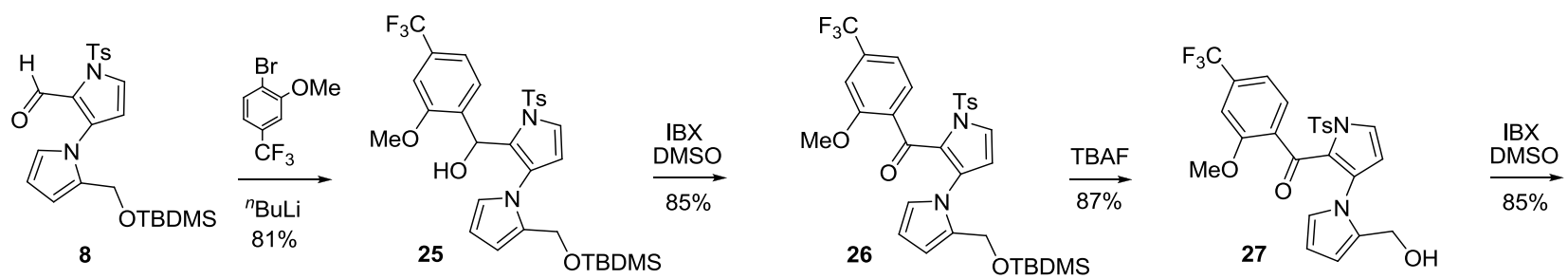

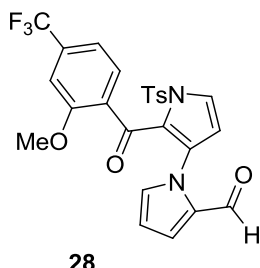

28
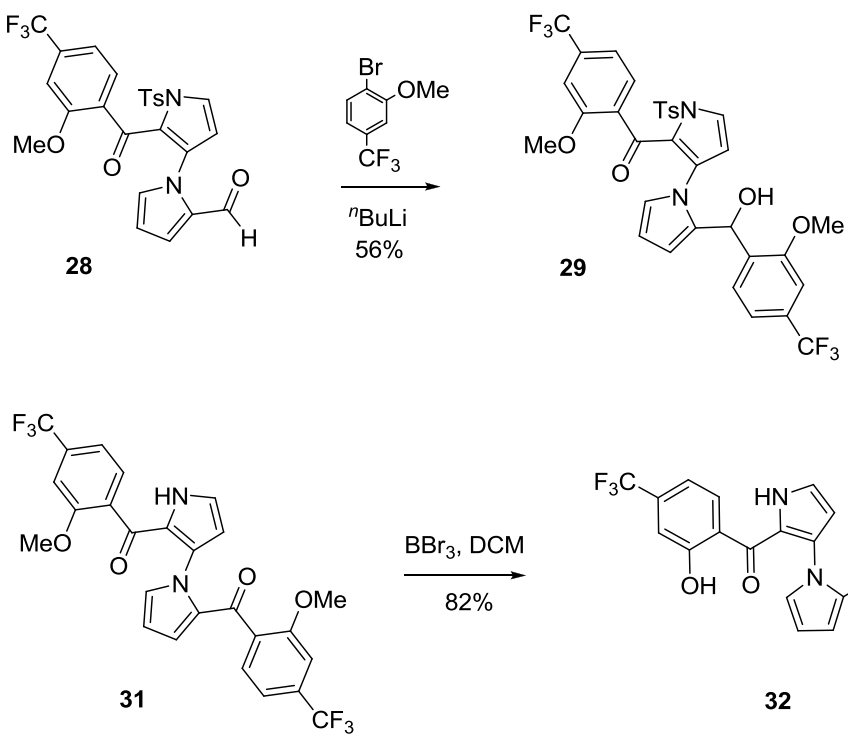
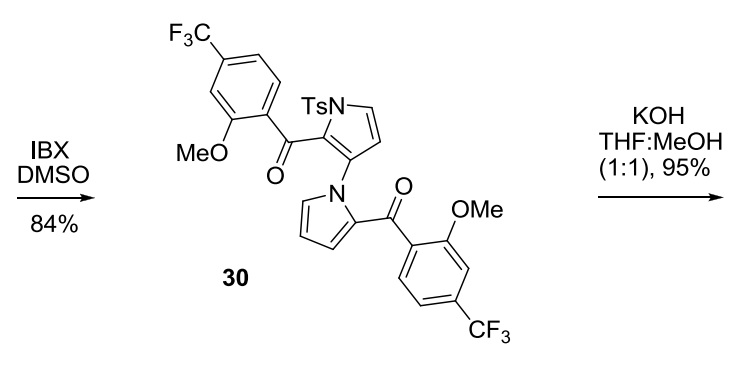

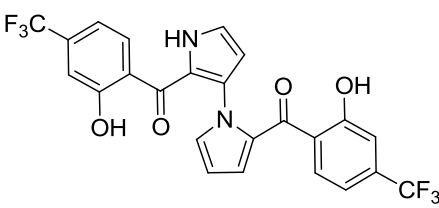

32

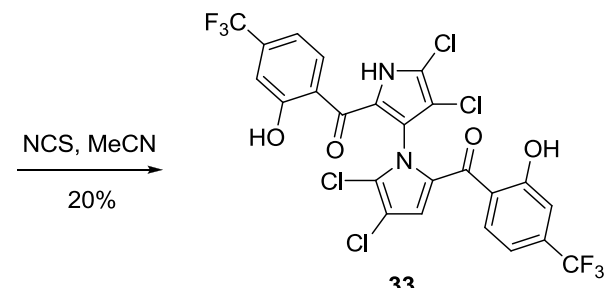

33

A nine-step sequence to access symmetrical marinopyrrole derivative $\mathbf{3 3}$ is shown in Scheme 4. Similar to the synthetic route towards compound 19 in Scheme 2, (2-methoxy-4-(trifluoromethyl) phenyl)lithium was added to aldehyde 8 followed by oxidation of $\mathbf{2 5}$ by IBX in DMSO to afford 26. Second addition of (2-methoxy-4-(trifluoromethyl)phenyl)lithium to aldehyde $\mathbf{2 8}$, generated by 
removal of TBDMS in 26 with TBAF followed by IBX oxidation of 27, furnished 29. As with the synthesis of compound 14 in Scheme 2, double alkylation on both aldehyde and ketone in $\mathbf{2 8}$ occurred, furnishing both 29 as a desired product in 56\% yield and diol byproduct 29A in $15 \%$ yield (Figure 1 and Experimental Section). However, no oxazepine byproduct was observed, presumably due to stabilization of precursor 29A by electron withdrawing $\mathrm{CF}_{3}$ groups in the para-position of phenyl rings. Diketone 30 was obtained after oxidation of 29 with IBX in DMSO in $84 \%$ yield. Removal of the tosyl group in $\mathbf{3 0}$ afforded $\mathbf{3 1}$, which was then subjected to demethylation using $\mathrm{BBr}_{3}$ in $\mathrm{DCM}$ in $82 \%$ yield. The final compound $\mathbf{3 3}$ was obtained after tetrachlorination of $\mathbf{3 2}$ with NCS in MeCN.

\subsection{SAR Studies}

After we achieved the first total synthesis of $( \pm$ )-marinopyrrole A (1) and 12 derivatives [12], their activity against seven groups of Gram-positive and three Gram-negative pathogens were evaluated. The results are reported here. Vancomycin was used as a positive control in all experiments. The potency of the compound was determined and expressed as minimum inhibitory concentration (MIC). As shown in Figure 2, the parent compound $\mathbf{1}$ demonstrated antibiotic activity comparable to that of vancomycin. The de-halogenated precursor 10, which lacks the tetrachloro substituents on the bispyrrole, exhibited $>64$ fold lower activity ( $\mathrm{MIC}>32 \mu \mathrm{g} / \mathrm{mL}$ ) against the pathogens tested. This result indicates that four chloro atoms on the pyrrole rings play an important role for antibiotic activity. The hydroxyl group in the ortho-position of the phenyl ring (1) is critical. Replacement of the hydroxyl group with other substituents such as $\mathrm{H}, \mathrm{F}, \mathrm{OMe}$, or $\mathrm{CF}_{3}$ led to lower activity or to a complete loss of activity (cf., 1c, 1d, $\mathbf{1 g}, \mathbf{1 j}$, and $\mathbf{1 n}$, Figure 2). Besides forming an internal hydrogen bond with the ketone moiety, as described for marinopyrrole $\mathrm{B}$ ( $3^{\prime}-\mathrm{Br}$ analogue of $\left.\mathbf{1}\right)$ [10], the hydroxyl group in $\mathbf{1}$ probably serves similarly as a hydrogen bond donor rather than a hydrogen bond acceptor when binding to the targets. This observation was supported by the fact that compounds $1 \mathbf{c}$ and $1 \mathbf{n}$, which possess a hydrogen bond acceptor, showed significant loss of activity. An electron-withdrawing group seems to be tolerated in the meta- and para-positions of the phenyl ring and the size of the

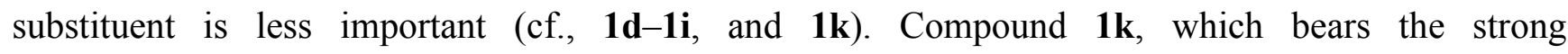
electron-withdrawing group $\mathrm{CF}_{3}$ in the para-position and lacks the key hydroxyl group in the ortho-position, exhibited the most potent activity against MRSE compared with the parent compound $\mathbf{1}$, vancomycin, and other derivatives. Although an electron-donating group in the para-position may reduce potency, compound $\mathbf{1 m}$ (bearing a hydroxyl group in the ortho-position) also showed activities against the tested pathogens MSSA, MRSA, ORSA (oxacillin-resistant Staphylococcus aureus), MRSE, and VRE (vancomycin-resistant Enterococcus faecalis) comparable to 1. This result reinforces further that the hydroxyl group in the ortho-position of the phenyl ring is pivotal. All compounds are inactive against Gram-negative pathogens $K$. pneumoniae, P. aeruginosa, and E. coli. With the preliminary SAR data acquired from the initial set of marinopyrrole derivatives in hand as shown in Figure 2, design of several symmetrical marinopyrrole congeners was focused on the substitutions in both ortho- and para-positions of the phenyl rings. Keeping the ortho-hydroxyl and meta-chloro groups in each ring constant, the para-methoxy was replaced by hydroxyl, furnishing compound 19 (Scheme 2) to see whether hydrogen bond donors or hydrogen bond acceptors in the para-position are preferred (comparing the activity with compound $\mathbf{1 m}$ ). Compound $\mathbf{2 4}$, bearing two hydroxyl groups in 
both ortho- and para-positions, was designed and synthesized (Scheme 3) to probe if hydrogen bond donors are favored in both ortho- and para-positions. Compound 33 was designed and synthesized (Scheme 4) based on the SAR information obtained from compound $\mathbf{1}$ and 1k. As shown in Figure 2, compound $1 \mathbf{k}$ demonstrated anti-MRSE activity in the range similar to that of $\mathbf{1}$, but with greater potency than that of vancomycin. However, 1k showed much lower activity against the other pathogens.

Figure 2. In vitro activity of marinopyrrole A and an initial set of derivatives ${ }^{\mathrm{a}}$.

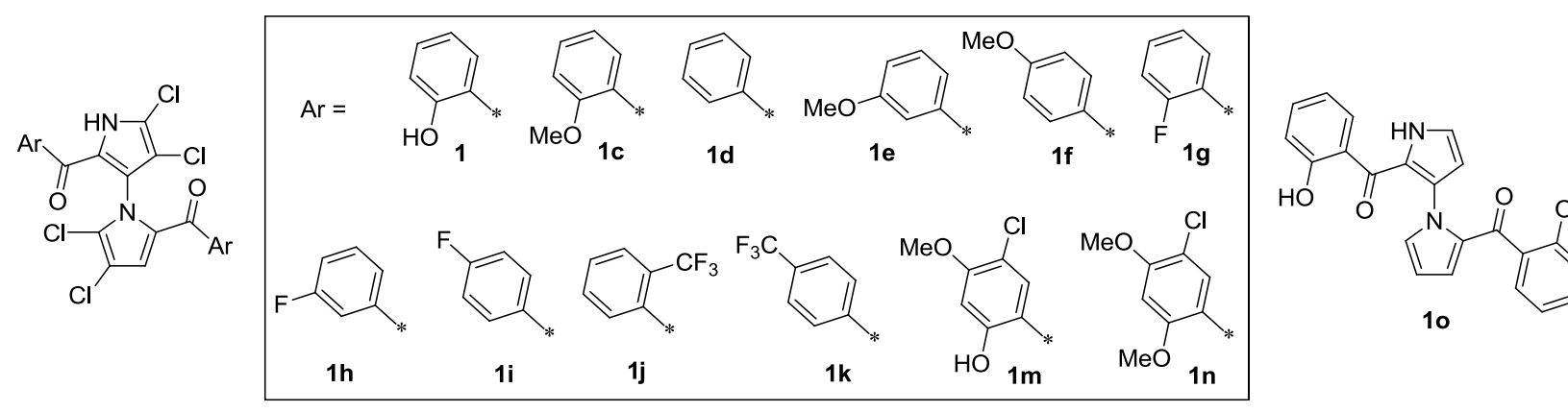

\begin{tabular}{|c|c|c|c|c|c|c|c|c|c|c|}
\hline Pathogens & $\operatorname{MSSA}^{c}$ & MRSA $^{d}$ & MRSE $^{\mathrm{e}}$ & $\begin{array}{c}\text { VRE } \\
\text { WHO-3 }^{f}\end{array}$ & $\begin{array}{c}\text { ORSA } \\
\text { WHO-25 }^{\mathrm{g}}\end{array}$ & $\begin{array}{c}\text { MRSA } \\
\text { WHO-31 }^{\text {h }}\end{array}$ & $V_{R E}{ }^{i}$ & K. penumoniae & $P$. aeruginosa & E. coli \\
\hline $\begin{array}{c}\text { Number of } \\
\text { isolates }\end{array}$ & 10 & 10 & 3 & 1 & 1 & 1 & 2 & 4 & 4 & 4 \\
\hline 1 & $0.5-1$ & 1 & $0.06-1$ & $0.5-1$ & 1 & 1 & $16-128$ & $>128$ & $>128$ & $>128$ \\
\hline $1 \mathrm{c}$ & $4-16$ & $4-16$ & $2-4$ & 2 & 8 & 4 & $>128$ & $>128$ & $>128$ & $>128$ \\
\hline 1d & $2-8$ & $4-8$ & $0.5-4$ & 2 & 4 & 4 & $>128$ & $>128$ & $>128$ & $>128$ \\
\hline $1 \mathrm{e}$ & $>128$ & $>128$ & $>128$ & $>128$ & $>128$ & $>128$ & $>128$ & $>128$ & $>128$ & $>128$ \\
\hline 1f & $>128$ & $>128$ & $>128$ & $>128$ & $>128$ & $>128$ & $>128$ & $>128$ & $>128$ & $>128$ \\
\hline $1 \mathrm{~g}$ & $>128$ & $>128$ & $>128$ & $>128$ & $>128$ & $>128$ & $>128$ & $>128$ & $>128$ & $>128$ \\
\hline 1h & $4-16$ & $>64$ & $0.13-1$ & 4 & 4 & 4 & $>128$ & $>128$ & $>128$ & $>128$ \\
\hline $\mathbf{1 i}$ & $4-16$ & $8-16$ & $0.25-4$ & 4 & 8 & 4 & $>128$ & $>128$ & $>128$ & $>128$ \\
\hline $1 \mathrm{j}$ & $>128$ & $>128$ & $>128$ & $>128$ & $>128$ & $>128$ & $>128$ & $>128$ & $>128$ & $>128$ \\
\hline $1 \mathrm{k}$ & $8-32$ & $32-64$ & $0.03-4$ & 8 & 8 & 8 & $>128$ & $>128$ & $>128$ & $>128$ \\
\hline $1 \mathrm{~m}$ & $2-8$ & $2-8$ & $0.25-4$ & 0.5 & 4 & 4 & $>128$ & $>128$ & $>128$ & $>128$ \\
\hline 1n & $>64$ & $>64$ & $>64$ & $>64$ & $>64$ & $>64$ & $>64$ & $>64$ & $>64$ & $>64$ \\
\hline 10 & $>32$ & $>32$ & $>32$ & $>32$ & $>32$ & $>32$ & $>32$ & $>128$ & $>128$ & $>128$ \\
\hline $\operatorname{Van}^{b}$ & $0.5-1$ & $0.25-0.5$ & $0.13-0.5$ & $>64$ & 2 & 0.5 & $>128$ & $>128$ & $>128$ & $>128$ \\
\hline
\end{tabular}

${ }^{\text {a }} \mathrm{MIC}$ in $\mu \mathrm{g} / \mathrm{mL}$, synthesis of compounds 1-10 was reported previously [12], except for those marked with WHO, all pathogens were isolated between July 2008 and October 2009 in hospitals located in Beijing, Guangzhou, Sichuan, Shandong and Jiangsu Province;

${ }^{\mathrm{b}}$ Vancomycin; ${ }^{\mathrm{c}}$ Methicillin-susceptible Staphylococcus aureus; ${ }^{\mathrm{d}}$ Methicillin-resistant Staphylococcus aureus; ${ }^{\mathrm{e}}$ Methicillin-resistant Staphylococcus epidermidis; ${ }^{\mathrm{f}}$ Moderately vancomycin-resistant Enterococcus faecium with the VanA gene; ${ }^{\mathrm{g}}$ Oxacillin-resistant Staphylococcus aureus; ${ }^{\mathrm{h}}$ Methicillin-resistant Staphylococcus aureus with the mecA gene and PBP2a; ${ }^{\mathrm{i}}$ Highly vancomycin-resistant Enterococcus faecalis.

\subsection{In Vitro Antibacterial Activity}

A preliminary evaluation of $\mathbf{1}$ and 12 marinopyrrole derivatives showed that they were active in various magnitudes against seven groups of Gram-positive pathogens and inactive against three 
Gram-negative pathogens (Figure 2). The parent compound 1 exhibited potency similar to that of vancomycin against the clinical isolates of methicillin-susceptible Staphylococcus aureus (MSSA), methicillin-resistant Staphylococcus aureus (MRSA), methicillin-resistant Staphylococcus epidermidis (MRSE), and non-clinical isolates of MRSA (WHO-31) and oxacillin-resistant Staphylococcus aureus (ORSA, WHO-25). Design and synthesis of marinopyrrole A derivatives based on the initial results of SAR studies led to novel derivatives 19, 24, and 33 using our recently optimized chemistries (vide supra). Among these derivatives as shown in Figure 3, compound 19 showed 4-16 fold decreased potency against MRSA and 2-16 fold against MRSE, respectively, when compared with compound 1m. The only structural difference is the para-hydroxyl (19) and para-methoxy (1m) substitution on the phenyl groups. Compound 24, bearing the same para-hydroxyl but lacking meta-chloro when compared with 19, exhibited similar potency to that of $\mathbf{1 m}$. Compound $\mathbf{3 3}$ bearing both a strong electron-withdrawing group $\left(\mathrm{CF}_{3}\right)$ in the para-position and an ortho-hydroxyl group exhibited the most potent antibacterial activity. As shown in Figure 3, compound 33 is eight-fold and four-fold more potent than vancomycin and $\mathbf{1}$ against MSSA, respectively. Compound $\mathbf{3 3}$ is also 2-4 fold more potent than both vancomycin and 1 against MRSA. Most significantly, compound 33 with MIC of $8 \mathrm{ng} / \mathrm{mL}$ is $>62$ fold and $>31$ fold more potent than vancomycin and 1 against MRSE, respectively. With respect to the antibacterial activities of $\mathbf{3 3}$ and $\mathbf{1 k}$, which lack the ortho-hydroxyl group, compound 33 showed at least 128, 64, and 4 fold more potent than 1k against MRSA, MSSA, and MRSE, respectively. This result further reinforces that the perihydroxyl group is crucial. The effect of the electron withdrawing $\mathrm{CF}_{3}$ group in $\mathbf{3 3}$ on the $\mathrm{p} K_{\mathrm{a}}$ of the phenols and lipophilicity may play an essential role in activity.

Figure 3. In vitro activity and physicochemical properties of marinopyrrole $\mathrm{A}$ and new derivatives ${ }^{a}$.

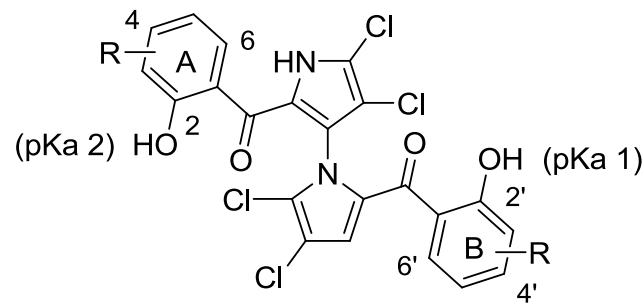

\begin{tabular}{|c|c|c|c|c|c|c|c|c|c|c|}
\hline Pathogens & Substituent & $\operatorname{MSSA}^{c}$ & MRSA $^{d}$ & MRSE $^{\text {e }}$ & WHO-3 $^{f}$ & WHO-25 $^{\mathrm{g}}$ & WHO-31 ${ }^{\text {h }}$ & $\mathbf{p} K_{\mathrm{a}} \mathbf{1}^{\mathrm{i}}$ & $\mathrm{p} K_{\mathrm{a}} 2^{\mathrm{i}}$ & $C \log p^{i}$ \\
\hline 1 & $\mathrm{R}=\mathrm{H}$ & 0.5 & $0.5-1$ & 0.25 & 1 & 1 & 1 & 7.8 & 8.4 & 5.8 \\
\hline 19 & $\mathrm{R}=5,5^{\prime}-\mathrm{Cl}, 4,4^{\prime}-\mathrm{OH}$ & 32 & 32 & $4-8$ & 4 & 8 & 8 & 8.0 & 8.6 & 6.0 \\
\hline 24 & $\mathrm{R}=4,4^{\prime}-\mathrm{OH}$ & 2 & 2 & $2-8$ & 4 & 4 & 2 & 8.7 & 9.3 & 5.0 \\
\hline 33 & $\mathrm{R}=4,4^{\prime}-\mathrm{CF}_{3}$ & 0.125 & $0.13-0.25$ & $<0.008$ & 0.5 & 1 & 1 & 7.3 & 7.9 & 7.3 \\
\hline $\operatorname{Van}^{b}$ & & 1 & $0.5-1$ & $0.5-1$ & $>128$ & 4 & 1 & $\mathrm{ND}^{\mathrm{j}}$ & $\mathrm{ND}^{\mathrm{j}}$ & $\mathrm{ND}^{\mathrm{j}}$ \\
\hline
\end{tabular}

${ }^{\mathrm{a}} \mathrm{MIC}$ in $\mu \mathrm{g} / \mathrm{mL}$, except for those marked with WHO, all pathogens were isolated in recent 2-3 years from hospitals located in Beijing, Guangzhou, Sichuan, Shandong and Jiangsu Province; ${ }^{\mathrm{b}}$ Vancomycin; ${ }^{\mathrm{c}}$ Methicillin-susceptible Staphylococcus aureus, data from 8 isolates; ${ }^{\mathrm{d}}$ Methicillin-resistant Staphylococcus aureus, data from $\mathbf{8}$ isolates; ${ }^{\mathrm{e}}$ Methicillin-resistant Staphylococcus epidermidis, data from 4 isolates; ${ }^{\mathrm{f}}$ Moderately vancomycin-resistant Enterococcus faecium with the VanA gene; ${ }^{\mathrm{g}}$ Oxacillin-resistant Staphylococcus aureus;

h Methicillin-resistant Staphylococcus aureus with the mecA gene and PBP2a; i Calculated using ChemAxon Software Version 5.12.3; ${ }^{\mathrm{j}}$ Not determined. 


\subsection{Physicochemical Properties of the Marinopyrroles}

Both $\mathrm{p} K_{\mathrm{a}}$ and $\log p$ values were calculated using ChemAxon Software Version 5.12.3 [20,21]. The $\mathrm{p} K_{\mathrm{a}}$ values of marinopyrrole $\mathrm{A}(\mathbf{1})$ are predicted to be $7.8\left(\mathrm{p} K_{\mathrm{a}} 1\right)$ and $8.4\left(\mathrm{p} K_{\mathrm{a}} 2\right)$, respectively (Figure 3). The difference in $\mathrm{p} K_{\mathrm{a}}$ values for the hydroxyl group in ring $\mathrm{A}$ and ring $\mathrm{B}$ is presumably due to the axially chiral environment. The $\mathrm{p} K_{\mathrm{a}}$ values of 1 are 1.6-2.2 $\log$ units lower than that of phenol $\left(\mathrm{p} K_{\mathrm{a}}=9.98\right.$ [22]). Equilibrium may exist between open conformations and closed conformations in 1, similar to those in a recent report of intramolecular hydrogen bonding in medicinal chemistry [23]. In the open forms, both perihydroxyl and carbonyl groups are available for hydrogen bond interactions as a donor and an acceptor, respectively. Both polar groups in the open forms can interact with solvents, intermolecular molecules, or protein targets. While in the closed forms, both polar groups form a stable six-membered ring system via internal hydrogen bonds resulting in more lipophilic molecules. The Fenical group reported the X-ray structure of marinopyrrole B ( 3 '-Br analog of 1$)$ that confirmed the intramolecular hydrogen bonds between the perihydroxyl and the carbonyl group [10]. These intramolecular hydrogen bond interactions contribute to not only lowering the $\mathrm{p} K_{\mathrm{a}}$ values but also increasing its lipophilicity [23]. The calculated $\log p$ value of $\mathbf{1}$ is 5.8, which marginally violates the rule of five (RO5), drug-like properties formulated by Lipinski [24]. The calculated $\log p$ values of $\mathbf{2 4}$ obeyed the RO5, presumably due to the presence of more hydrophilic hydroxyl group. The $\mathrm{p} K_{\mathrm{a}}$ and $C \log p$ values of 33 are predicted to be 7.3-7.9 and 7.3, $0.5 \log$ units lower in $\mathrm{p} K_{\mathrm{a}}$ and $1.5 \log$ units higher in $C \log p$ than those of $\mathbf{1}$, respectively. These changes are due to additional electron-withdrawing $\mathrm{CF}_{3}$ group. Although the marinopyrroles reported in this paper are most likely in the closed forms like marinopyrrole B reported [10], it is possible for them to adopt the open forms if stronger hydrogen bonds between the marinopyrroles and the protein target predominate. In this case, the internal hydrogen bonds of marinopyrroles are weakened and the resulting molecules are expected to have $\operatorname{lower} \log p$ values. Notwithstanding that there are no direct correlations between the $\mathrm{p} K_{\mathrm{a}}, \mathrm{Clog} p$ and in vitro antibiotic activity of the marinopyrroles discussed above, it is important to understand physicochemical properties when their SARs are optimized.

\section{Experimental Section}

\subsection{Synthesis of Marinopyrrole Derivatives}

All chemicals were purchased from commercial suppliers and used without further purification. All solvents were dried and distilled before use. Tetrahydrofuran was distilled from sodium/benzophenone. Dichloromethane and acetonitrile were distilled over calcium hydride. Flash column chromatography was performed with silica gel (200-300 mesh). ${ }^{1} \mathrm{H}$ NMR spectra were recorded at either $400 \mathrm{MHz}$ or $600 \mathrm{MHz}$ at ambient temperature. ${ }^{13} \mathrm{C}$ NMR spectra were recorded at either 100 or $150 \mathrm{MHz}$ at ambient temperature. Infrared spectra were recorded on a spectrophotometer (Perkin-Elmer Spectrum 100). Copies of NMR spectra of all the described compounds are provided in a Supporting Information Document. Melting points were determined with melting point apparatus (Fukai X-4). High resolution mass spectra were performed by electrospray ionization (ESI) on an Agilent ESI-TOF LC-MS 6200 system. Analytical HPLC was performed on an Agilent 1100 series with diode array detectors and auto samplers. All tested compounds possessed a purity of not less than $95 \%$. 
2-(Hydroxymethyl)-1'-tosyl-1'H-1,3'-bipyrrole-2'-carbaldehyde (7). To a solution of (1'-tosyl-1'H-1, 3'-bipyrrole-2,2'-diyl)dimethanol 6 obtained from ethyl 3-amino-1 $H$-pyrrole-2-carboxylate hydrochloride 2 in three steps [3] $(2.00 \mathrm{~g}, 5.8 \mathrm{mmol})$ in DMSO $(30 \mathrm{~mL})$ was added IBX $(1.78 \mathrm{~g}, 6.4 \mathrm{mmol})$ at room temperature. After being stirred for $5 \mathrm{~h}$, the mixture was quenched with water $(50 \mathrm{~mL})$. The suspension was filtered and the filtrate was extracted with EtOAc $(25 \mathrm{~mL} \times 3)$. The combined organic layers were dried over anhydrous sodium sulfate, filtered and concentrated in vacuum. The residue was purified by flash column chromatography $\left(25 \%\right.$ EtOAc/petroleum ether, $\left.R_{\mathrm{f}}=0.2\right)$ to give $7(1.43 \mathrm{~g}, 72 \%)$ as a liquid. ${ }^{1} \mathrm{H}$ NMR (400 MHz, $\left.\mathrm{CDCl}_{3}\right) \delta 2.43(\mathrm{~s}, 3 \mathrm{H}), 2.87$ (br, s, 1H), $4.44(\mathrm{~s}, 2 \mathrm{H}), 6.33$ (d, J=3.2 Hz, $1 \mathrm{H}), 6.38(\mathrm{dd}, J=4.0,2.8 \mathrm{~Hz}, 1 \mathrm{H}), 7.05(\mathrm{~s}, 1 \mathrm{H}), 7.09(\mathrm{dd}, J=4.4,2.0 \mathrm{~Hz}, 1 \mathrm{H}), 7.31(\mathrm{~d}, J=3.6 \mathrm{~Hz}$, $1 \mathrm{H}), 7.35(\mathrm{~d}, J=8.4 \mathrm{~Hz}, 2 \mathrm{H}), 7.82(\mathrm{~d}, J=8.4 \mathrm{~Hz}, 2 \mathrm{H}), 9.46(\mathrm{~s}, 1 \mathrm{H}) \mathrm{ppm} ;{ }^{13} \mathrm{C} \mathrm{NMR}\left(\mathrm{CDCl}_{3}, 100 \mathrm{MHz}\right)$ $\delta$ 21.70, 53.00, 111.00, 111.16, 121.55, 123.57, 127.11, 127.11, 127.32, 128.70, 130.24, 130.24, 132.90, 132.99, 135.55, 145.77, 179.27 ppm; HRMS $\left(\mathrm{M}+\mathrm{Na}^{+}\right)$calcd. for $\mathrm{C}_{17} \mathrm{H}_{16} \mathrm{~N}_{2} \mathrm{NaO}_{4} \mathrm{~S} 367.0728$, found 367.0733; IR (KBr) 3425, 3118, 2924, 2875, 2730, 1662, 1595, 1369, 1317, 1177, 1086, 1012, 774,754 and $669 \mathrm{~cm}^{-1}$.

2-((tert-Butyldimethylsilyloxy)methyl)-1'-tosyl-1'H-1,3'-bipyrrole-2'-carbaldehyde (8). To a solution of $7(6.00 \mathrm{~g}, 17.4 \mathrm{mmol})$ in dry $\mathrm{CH}_{2} \mathrm{Cl}_{2}(60 \mathrm{~mL})$ was added imidazole $(2.37 \mathrm{~g}, 34.8 \mathrm{mmol})$ at room temperature. After being stirred for $5 \mathrm{~min}$, TBDMSCl $(5.30 \mathrm{~g}, 34.8 \mathrm{mmol})$ was added. The mixture was stirred for about $2.5 \mathrm{~h}$ and quenched with water $(50 \mathrm{~mL})$ and extracted with $\mathrm{CH}_{2} \mathrm{Cl}_{2}(25 \mathrm{~mL} \times 3)$. The combined organic layers were dried over anhydrous sodium sulfate, filtered and concentrated in vacuum. The residue was purified by flash column chromatography $(20 \%$ EtOAc/petroleum ether, $\left.R_{\mathrm{f}}=0.35\right)$ to give $8(5.59 \mathrm{~g}, 70 \%)$ as a liquid. ${ }^{1} \mathrm{H} \mathrm{NMR}\left(400 \mathrm{MHz}, \mathrm{CDCl}_{3}\right) \delta-0.04(\mathrm{~s}, 6 \mathrm{H}), 0.82(\mathrm{~s}$, $9 \mathrm{H}), 2.42(\mathrm{~s}, 3 \mathrm{H}), 4.61(\mathrm{~s}, 2 \mathrm{H}), 6.34-6.36(\mathrm{~m}, 2 \mathrm{H}), 7.03(\mathrm{t}, J=1.6 \mathrm{~Hz}, 1 \mathrm{H}), 7.11(\mathrm{dd}, J=4.0$, $1.6 \mathrm{~Hz}, 1 \mathrm{H}), 7.26(\mathrm{~d}, J=2.4 \mathrm{~Hz}, 1 \mathrm{H}), 7.29(\mathrm{~d}, J=8.4 \mathrm{~Hz}, 2 \mathrm{H}), 7.85$ (d, $J=8.4 \mathrm{~Hz}, 2 \mathrm{H}), 9.46$ (s, $1 \mathrm{H}) \mathrm{ppm} ;{ }^{13} \mathrm{C} \mathrm{NMR}\left(\mathrm{CDCl}_{3}, 100 \mathrm{MHz}\right) \delta-5.67,-5.67,18.44,21.65,25.88,25.88,25.88,53.34$, $110.65,111.12,121.08,121.73,127.09,127.09,127.46,128.65,129.90,129.90,132.11,133.25$, 136.34, 145.19, 179.04 ppm; HRMS $\left(\mathrm{M}+\mathrm{Na}^{+}\right)$calcd. for $\mathrm{C}_{23} \mathrm{H}_{30} \mathrm{~N}_{2} \mathrm{NaO}_{4} \mathrm{SSi}$ 481.1593, found 481.1591; IR (KBr) 3444, 3130, 2952, 2928, 2857, 2787, 1665, 1595, 1463, 1336, 1252, 1182, 1009 , $841,668,604 \mathrm{~cm}^{-1}$.

(4-(Benzyloxy)-2-methoxyphenyl)(2-((tert-butyldimethylsilyloxy)methyl)-1'-tosyl-1'H-1,3'-bipyrrol2'-yl)methanol (10). To a solution of 4-(benzyloxy)-1-bromo-2-methoxybenzene (9) (0.80 g, $2.7 \mathrm{mmol})$ in dry THF $(5 \mathrm{~mL})$ at $-78{ }^{\circ} \mathrm{C}$ under $\mathrm{N}_{2}$ was slowly added $N$-BuLi $(1.09 \mathrm{~mL}, 2.5 \mathrm{M}$ in $N$-pentane, $2.7 \mathrm{mmol})$. After being stirred for $40 \mathrm{~min}$, a solution of $8(0.50 \mathrm{~g}, 1.1 \mathrm{mmol})$ in dry THF $(1.5 \mathrm{~mL})$ was added slowly via a syringe. The mixture was stirred for about $1 \mathrm{~h}$ and quenched by addition of a saturated aqueous $\mathrm{NH}_{4} \mathrm{Cl}(15 \mathrm{~mL})$ solution and extracted with EtOAc $(15 \mathrm{~mL} \times 3)$. The combined organic layers were dried over anhydrous sodium sulfate, filtered and concentrated in vacuum. The residue was purified by flash column chromatography $\left(15 \% \mathrm{EtOAc} /\right.$ petroleum ether, $\left.R_{\mathrm{f}}=0.2\right)$ to give $10(0.66 \mathrm{~g}, 90 \%)$ as a pale yellow solid. mp 39.3-41.7 ${ }^{\circ} \mathrm{C} ;{ }^{1} \mathrm{H}$ NMR $\left(400 \mathrm{MHz}, \mathrm{CDCl}_{3}\right) \delta-0.03$ (s, $3 \mathrm{H}),-0.02(\mathrm{~s}, 3 \mathrm{H}), 0.84(\mathrm{~s}, 9 \mathrm{H}), 2.40(\mathrm{~s}, 3 \mathrm{H}), 2.73(\mathrm{~d}, J=5.2 \mathrm{~Hz}, 1 \mathrm{H}), 3.68(\mathrm{~s}, 3 \mathrm{H}), 4.38(\mathrm{~d}, J=12.0 \mathrm{~Hz}$, $1 \mathrm{H}), 4.63(\mathrm{~d}, J=11.6 \mathrm{~Hz}, 1 \mathrm{H}), 5.04(\mathrm{~s}, 2 \mathrm{H}), 5.74(\mathrm{~d}, J=5.2 \mathrm{~Hz}, 1 \mathrm{H}), 6.02(\mathrm{t}, J=2.0 \mathrm{~Hz}, 1 \mathrm{H}), 6.12(\mathrm{t}$, $J=3.2 \mathrm{~Hz}, 1 \mathrm{H}), 6.28(\mathrm{~d}, J=3.6 \mathrm{~Hz}, 1 \mathrm{H}), 6.47-6.49(\mathrm{~m}, 2 \mathrm{H}), 6.66(\mathrm{t}, J=2.4 \mathrm{~Hz}, 1 \mathrm{H}), 7.14-7.17(\mathrm{~m}$, 2H), $7.28(\mathrm{~d}, J=10.4 \mathrm{~Hz}, 2 \mathrm{H}), 7.33-7.44(\mathrm{~m}, 5 \mathrm{H}), 7.85(\mathrm{~d}, J=8.4 \mathrm{~Hz}, 2 \mathrm{H}) \mathrm{ppm} ;{ }^{13} \mathrm{C} \mathrm{NMR}\left(\mathrm{CDCl}_{3}\right.$, 
$100 \mathrm{MHz}) \delta-5.70,-5.70,18.44,21.49,25.87,25.87,25.87,53.07,55.21,63.61,69.97,99.11,104.80$, $107.70,107.96,111.32,121.26,123.50,123.74,126.97,126.97,127.46,127.46,127.87,128.01$, 128.31, 128.31, 128.46, 129.21, 129.67, 129.67, 136.36, 136.40, 136.79, 144.84, 157.16, 159.22 ppm; HRMS ( $\left.\mathrm{M}+\mathrm{Na}^{+}\right)$calcd. for $\mathrm{C}_{37} \mathrm{H}_{44} \mathrm{~N}_{2} \mathrm{NaO}_{6} \mathrm{SSi}$ 695.2587, found 695.2598; IR (KBr) 3450, 3032, 2953, 2885, 2855, 1707, 1611, 1591, 1502, 1467, 1376, 1333, 1255, 1180, 1021, 838, 700, $600 \mathrm{~cm}^{-1}$.

(4-(Benzyloxy)-2-methoxyphenyl)(2-((tert-butyldimethylsilyloxy)methyl)-1'-tosyl-1'H-1,3'-bipyrrol2'-yl)methanone (11). To a solution of 10 (3.67 g, $5.5 \mathrm{mmol})$ in dry DMSO (40 mL) was added IBX (3.06 g, $10.9 \mathrm{mmol})$ at room temperature. The mixture was allowed to warm up to $30{ }^{\circ} \mathrm{C}$ and stir for about $2 \mathrm{~h}$. The mixture was quenched with water $(60 \mathrm{~mL})$ and extracted with EtOAc $(25 \mathrm{~mL} \times 3)$. The combined organic layers were dried over anhydrous sodium sulfate, filtered and concentrated in vacuum. The residue was purified by flash column chromatography $(15 \%$ EtOAc/petroleum ether, $\left.R_{\mathrm{f}}=0.3\right)$ to give $11(3.00 \mathrm{~g}, 82 \%)$ as a pale brown solid. mp $44.7-47.0{ }^{\circ} \mathrm{C} ;{ }^{1} \mathrm{H} \mathrm{NMR}(400 \mathrm{MHz}$, $\left.\mathrm{CDCl}_{3}\right) \delta 0.004(\mathrm{~s}, 3 \mathrm{H}), 0.01(\mathrm{~s}, 3 \mathrm{H}), 0.86(\mathrm{~s}, 9 \mathrm{H}), 2.40(\mathrm{~s}, 3 \mathrm{H}), 3.73(\mathrm{~s}, 3 \mathrm{H}), 4.67(\mathrm{~s}, 2 \mathrm{H}), 5.10(\mathrm{~s}, 2 \mathrm{H})$, $6.21(\mathrm{t}, J=3.6 \mathrm{~Hz}, 1 \mathrm{H}), 6.30(\mathrm{~d}, J=3.6 \mathrm{~Hz}, 1 \mathrm{H}), 6.52-6.54(\mathrm{~m}, 2 \mathrm{H}), 6.69(\mathrm{dd}, J=4.0,1.6 \mathrm{~Hz}, 1 \mathrm{H})$, $7.06(\mathrm{~s}, 1 \mathrm{H}), 7.17(\mathrm{~d}, J=3.6 \mathrm{~Hz}, 1 \mathrm{H}), 7.26(\mathrm{~d}, J=7.2 \mathrm{~Hz}, 2 \mathrm{H}), 7.36-7.46(\mathrm{~m}, 6 \mathrm{H}), 7.84(\mathrm{~d}, J=8.4 \mathrm{~Hz}$, 2H) ppm; ${ }^{13} \mathrm{C} \mathrm{NMR}\left(\mathrm{CDCl}_{3}, 100 \mathrm{MHz}\right) \delta-5.53,-5.53,18.50,21.63,25.96,25.96,25.96,53.61$, 55.65, 70.22, 99.68, 104.56, 108.92, 111.55, 121.34, 122.70, 127.03, 127.03, 127.17, 127.62, 127.62, $128.22,128.69,128.69,129.79,130.04,130.04,131.65,131.65,132.33,132.90,136.45,136.80$, 144.72, 159.28, 161.84, 183.51 ppm; HRMS $\left(\mathrm{M}+\mathrm{H}^{+}\right)$calcd. for $\mathrm{C}_{37} \mathrm{H}_{43} \mathrm{~N}_{2} \mathrm{O}_{6} \mathrm{SSi}$ 671.2611, found 671.2607; IR (KBr) 3737, 3144, 2953, 2929, 2855, 1639, 1603, 1499, 1413, 1375, 1274, 1179, 1158 , $1026,840 \mathrm{~cm}^{-1}$.

(4-(Benzyloxy)-2-methoxyphenyl)(2-(hydroxymethyl)-1'-tosyl-1'H-1,3'-bipyrrol-2'-yl)methanone (12). To a solution of $\mathbf{1 1}(2.92 \mathrm{~g}, 4.4 \mathrm{mmol})$ in dry THF $(20 \mathrm{~mL})$ was added TBAF (3.41 g, $13.1 \mathrm{mmol})$ at room temperature. After being stirred for about $5 \mathrm{~h}$ at room temperature, the mixture was quenched with water $(25 \mathrm{~mL})$ and extracted with EtOAc $(15 \mathrm{~mL} \times 3)$. The combined organic layers were dried over anhydrous sodium sulfate, filtered and concentrated in vacuum. The residue was purified by flash column chromatography ( $\left.25 \% \mathrm{EtOAc/petroleum} \mathrm{ether,} R_{\mathrm{f}}=0.2\right)$ to give $\mathbf{1 2}(2.30 \mathrm{~g}, 95 \%)$ as a white solid. mp 55.7-58.3 ${ }^{\circ} \mathrm{C} ;{ }^{1} \mathrm{H}$ NMR (400 MHz, $\left.\mathrm{CDCl}_{3}\right) \delta 2.43(\mathrm{~s}, 3 \mathrm{H}), 3.76(\mathrm{~s}, 3 \mathrm{H}), 4.55(\mathrm{~s}, 1 \mathrm{H}), 5.10$ $(\mathrm{s}, 2 \mathrm{H}), 5.30(\mathrm{~s}, 2 \mathrm{H}), 6.24(\mathrm{dd}, J=4.0,2.4 \mathrm{~Hz}, 1 \mathrm{H}), 6.31(\mathrm{~d}, J=3.6 \mathrm{~Hz}, 1 \mathrm{H}), 6.52-6.56(\mathrm{~m}, 2 \mathrm{H}), 6.65$ $(\mathrm{dd}, J=4.0,1.6 \mathrm{~Hz}, 1 \mathrm{H}), 7.00(\mathrm{t}, J=2.4 \mathrm{~Hz}, 1 \mathrm{H}), 7.27$ (d, $J=3.2 \mathrm{~Hz}, 1 \mathrm{H}), 7.30-7.45(\mathrm{~m}, 8 \mathrm{H}), 7.84$ $(\mathrm{d}, J=8.4 \mathrm{~Hz}, 2 \mathrm{H}) \mathrm{ppm} ;{ }^{13} \mathrm{C} \mathrm{NMR}\left(\mathrm{CDCl}_{3}, 100 \mathrm{MHz}\right) \delta 21.64,53.17,55.65,70.18,99.70,104.57$, $109.59,110.96,121.11,122.58,123.35,127.20,127.20,127.55,127.55,128.20,128.21,128.66$, $128.66,128.90,130.09,130.09,131.47,132.47,133.12,135.81,136.33,145.34,159.15,161.85$, 184.48 ppm; HRMS $\left(\mathrm{M}+\mathrm{H}^{+}\right)$calcd. for $\mathrm{C}_{31} \mathrm{H}_{29} \mathrm{~N}_{2} \mathrm{O}_{6} \mathrm{~S}$ 557.1746, found 557.1743; IR ( $\left.\mathrm{KBr}\right) 3436$, 2929, 2878, 1603, 1498, 1459, 1367, 1276, 1175, 1115, 1022, 867, $671 \mathrm{~cm}^{-1}$.

2'-(4-(Benzyloxy)-2-methoxybenzoyl)-1'-tosyl-1'H-1,3'-bipyrrole-2-carbaldehyde (13). To a solution of 12 (2.31 g, $4.2 \mathrm{mmol})$ in dry DMSO $(30 \mathrm{~mL})$ was added IBX $(2.33 \mathrm{~g}, 8.3 \mathrm{mmol})$ at room temperature. The mixture was allowed to warm up to $50{ }^{\circ} \mathrm{C}$ and stir for about $3 \mathrm{~h}$. The mixture was quenched with water $(40 \mathrm{~mL})$ and extracted with EtOAc $(15 \mathrm{~mL} \times 3)$. The combined organic layers were dried over anhydrous sodium sulfate, filtered and concentrated in vacuum. The residue was purified by flash column chromatography (20\% EtOAc/petroleum ether, $\left.R_{\mathrm{f}}=0.3\right)$ to give $\mathbf{1 3}(2.20 \mathrm{~g}, 96 \%)$ as a pale 
yellow solid. mp 132.7-135.0 ${ }^{\circ} \mathrm{C} ;{ }^{1} \mathrm{H}$ NMR (400 MHz, $\left.\mathrm{CDCl}_{3}\right) \delta 2.41$ (s, 3H), 3.81 (s, 3H), 4.99 (s, 2H), 6.27-6.30 (m, 2H), $6.45(\mathrm{~d}, J=2.0 \mathrm{~Hz}, 1 \mathrm{H}), 6.49$ (dd, $J=8.0,2.0 \mathrm{~Hz}, 1 \mathrm{H}), 6.73$ (dd, $J=3.6$, $1.6 \mathrm{~Hz}, 1 \mathrm{H}), 6.98(\mathrm{dd}, J=2.4,1.6 \mathrm{~Hz}, 1 \mathrm{H}), 7.17-7.20(\mathrm{~m}, 2 \mathrm{H}), 7.25-7.26(\mathrm{~m}, 3 \mathrm{H}), 7.34$ (d, $J=8.4 \mathrm{~Hz}$, 2H), $7.38(\mathrm{~d}, J=8.4 \mathrm{~Hz}, 1 \mathrm{H}), 7.63(\mathrm{~d}, J=3.2 \mathrm{~Hz}, 1 \mathrm{H}), 7.88$ (d, $J=8.4 \mathrm{~Hz}, 2 \mathrm{H}), 9.56$ (s, 1H) ppm; ${ }^{13} \mathrm{C} \mathrm{NMR}\left(\mathrm{CDCl}_{3}, 100 \mathrm{MHz}\right) \delta 21.70,55.65,70.17,99.64,104.78,110.13,111.57,121.95,122.69$, $125.22,127.62,127.62,127.69,128.04,128.04,128.21,128.68,128.68,130.03,130.03,131.59$, $132.02,134.07,134.78,136.41,139.25,145.95,159.37,162.13,177.08,183.45$ ppm; HRMS $\left(\mathrm{M}+\mathrm{H}^{+}\right)$calcd. for $\mathrm{C}_{31} \mathrm{H}_{27} \mathrm{~N}_{2} \mathrm{O}_{6} \mathrm{~S} 555.1590$, found 555.1600; IR (KBr) 3454, 3124, 3083, 2872, 2792, $1685,1633,1566,1440,1347,1169,1112,1026,763 \mathrm{~cm}^{-1}$.

(4-(Benzyloxy)-2-methoxyphenyl)(2-((4-(benzyloxy)-2-methoxyphenyl)(hydroxy)methyl)-1'-tosyl1'H-1,3'-bipyrrol-2'-yl)methanone (14). To a solution of 4-(benzyloxy)-1-bromo-2-methoxybenzene (9) $(198 \mathrm{mg}, 0.68 \mathrm{mmol})$ in dry THF $(5 \mathrm{~mL})$ at $-78^{\circ} \mathrm{C}$ under $\mathrm{N}_{2}$ was slowly added $N$-BuLi $(0.27 \mathrm{~mL}$, $2.5 \mathrm{M}$ in $\mathrm{N}$-pentane, $0.68 \mathrm{mmol})$. After being stirred for $30 \mathrm{~min}$, a solution of 13 (150 $\mathrm{mg}, 0.27 \mathrm{mmol})$ in dry THF $(1.5 \mathrm{~mL})$ was added slowly via a syringe. After the mixture was stirred at $-78{ }^{\circ} \mathrm{C}$ for $2 \mathrm{~h}$, the reaction was quenched by addition of a saturated aqueous solution of $\mathrm{NH}_{4} \mathrm{Cl}(10 \mathrm{~mL})$ and extracted with EtOAc $(10 \mathrm{~mL} \times 3)$. The combined organic layers were dried over anhydrous sodium sulfate, filtered and concentrated in vacuum. The residue was purified quickly by flash column chromatography $\left(20 \%\right.$ EtOAc/petroleum ether, $\left.R_{\mathrm{f}}=0.2\right)$ to give unstable $14(177 \mathrm{mg}, 85 \%)$ as a light red solid and 14A (10 mg, 5\%) as a light yellow solid. mp for 14, 76.5-77.4 ${ }^{\circ} \mathrm{C} ;{ }^{1} \mathrm{H}$ NMR $\left(600 \mathrm{MHz}, \mathrm{CDCl}_{3}\right) \delta 2.39$ (s, 3H), 3.38 (br s, 3H), 3.45 (s, 3H), $4.90(\mathrm{~d}, J=11.4 \mathrm{~Hz}, 1 \mathrm{H}), 4.94$ (d, $J=11.4 \mathrm{~Hz}, 1 \mathrm{H}), 5.01$ (br s, 2H), 5.78 (br s, 1H), $6.15(\mathrm{~d}, J=8.4 \mathrm{~Hz}, 1 \mathrm{H}), 6.18(\mathrm{~s}, 1 \mathrm{H}), 6.30(\mathrm{~s}, 1 \mathrm{H}), 6.35-6.46(\mathrm{~m}, 2 \mathrm{H}), 6.52$ (s, $1 \mathrm{H}), 7.04$ (s, 1H), 7.18 (br s, $1 \mathrm{H}), 7.28-7.42(\mathrm{~m}, 16 \mathrm{H}), 7.87(\mathrm{~d}, J=7.8 \mathrm{~Hz}, 2 \mathrm{H}) \mathrm{ppm} ;{ }^{13} \mathrm{C} \mathrm{NMR}$ $\left(\mathrm{CDCl}_{3}, 150 \mathrm{MHz}\right) \delta 21.59,54.85,55.56,61.78,69.69,70.00,98.22,99.63,100.55,104.06,104.23$, $108.66,111.62,120.16,122.53,123.22,126.26,127.26,127.26,127.48,127.48,127.52,127.52$, $127.78,127.87,128.20,128.41,128.41,128.57,128.57,129.75,129.75,130.03,131.52,132.41$, 135.98, 136.32, 137.07, 144.86, 156.26, 158.52, 158.81, 159.07, 161.46, 171.10 ppm; HRMS (M + $\left.\mathrm{Na}^{+}\right)$ calcd. for $\mathrm{C}_{45} \mathrm{H}_{40} \mathrm{~N}_{2} \mathrm{NaO}_{8} \mathrm{~S}$ 791.2403, found 791.2410; IR (KBr) 3423, 1608, 1502, 1454, 1411, 1372, $1278,1198,1175,1123,1034,945,738,697,593 \mathrm{~cm}^{-1}$.

4,4,6-Tris(4-(benzyloxy)-2-methoxyphenyl)-2-tosyl-4,6-dihydro-2H-dipyrrolo[2,1-c:3',4'-e][1,4] oxazepine (14A). mp 105.6-106.4 ${ }^{\circ} \mathrm{C} ;{ }^{1} \mathrm{H}$ NMR (400 MHz, $\left.\mathrm{CDCl}_{3}\right) \delta 2.25(\mathrm{~s}, 3 \mathrm{H}), 3.08(\mathrm{~s}, 3 \mathrm{H}), 3.55$ $(\mathrm{s}, 3 \mathrm{H}), 3.83(\mathrm{~s}, 3 \mathrm{H}), 4.95(\mathrm{~s}, 2 \mathrm{H}), 5.00(\mathrm{~s}, 4 \mathrm{H}), 5.59(\mathrm{~s}, 1 \mathrm{H}), 6.09$ (d, J = 2.4 Hz, 1H), 6.16-6.18 (m, $2 \mathrm{H}), 6.38-6.42(\mathrm{~m}, 4 \mathrm{H}), 6.50-6.51(\mathrm{~m}, 2 \mathrm{H}), 6.67(\mathrm{td}, J=8.8,2.4 \mathrm{~Hz}, 2 \mathrm{H}), 7.00-7.02(\mathrm{~m}, 6 \mathrm{H})$, $7.30-7.44(\mathrm{~m}, 15 \mathrm{H}), 7.72(\mathrm{dd}, J=8.8,2.4 \mathrm{~Hz}, 1 \mathrm{H}) \mathrm{ppm} ;{ }^{13} \mathrm{C} \mathrm{NMR}\left(\mathrm{CDCl}_{3}, 100 \mathrm{MHz}\right) \delta 21.68,54.24$, 54.69, 55.14, 67.95, 68.37, 68.62, 78.68, 98.24, 98.55, 98.63, 98.86, 99.70, 100.29, 103.14, 103.63, $103.91,103.97,105.72,107.05,109.16,117.71,118.71,119.37,120.79,122.51,124.31,125.42$, $125.42,125.52,126.38,126.38,126.58,126.58,126.84,126.99,127.47,127.47,127.47,127.47$, $127.59,127.59,128.40,128.40,128.49,128.59,129.78,131.74,135.03,135.96,136.14,136.84$, 142.76, 155.71, 157.34, 157.80, 157.85, 158.09, 158.73 ppm; HRMS $\left(\mathrm{M}+\mathrm{Na}^{+}\right)$calcd. for $\mathrm{C}_{59} \mathrm{H}_{52} \mathrm{~N}_{2} \mathrm{NaO}_{9} \mathrm{~S}$ 987.3291, found 987.3297; IR (KBr) 3429, 2925, 1609, 1585, 1502, 1453, 1416, $1262,1193,1139,1037,964,806,698,590 \mathrm{~cm}^{-1}$. 
(1'-Tosyl-1'H-1,3'-bipyrrole-2,2'-diyl)bis((4-(benzyloxy)-2-methoxyphenyl)methanone) (15). To a solution of $14(127 \mathrm{mg}, 0.17 \mathrm{mmol})$ in dry DMSO (4 mL) was stepwise added IBX (116 mg, $0.41 \mathrm{mmol}$ ) at room temperature. The mixture was allowed to warm up to $50{ }^{\circ} \mathrm{C}$ and stir for about $3.5 \mathrm{~h}$. The mixture was quenched with water $(10 \mathrm{~mL})$ and extracted with EtOAc $(10 \mathrm{~mL} \times 3)$. The combined organic layers were dried over anhydrous sodium sulfate, filtered, and concentrated in vacuum. The residue was purified by flash column chromatography $(20 \%$ EtOAc/petroleum ether, $\left.R_{\mathrm{f}}=0.2\right)$ to give $15(115 \mathrm{mg}, 90 \%)$ as a pale brown solid. mp $147.9-152.7{ }^{\circ} \mathrm{C} ;{ }^{1} \mathrm{H} \mathrm{NMR}(400 \mathrm{MHz}$, $\left.\mathrm{CDCl}_{3}\right) \delta 2.42(\mathrm{~s}, 3 \mathrm{H}), 3.64(\mathrm{~s}, 3 \mathrm{H}), 3.73(\mathrm{~s}, 3 \mathrm{H}), 4.98(\mathrm{~s}, 2 \mathrm{H}), 5.03(\mathrm{~s}, 2 \mathrm{H}), 5.87(\mathrm{t}, J=3.2 \mathrm{~Hz}$, $1 \mathrm{H}), 6.28-6.33(\mathrm{~m}, 3 \mathrm{H}), 6.42-6.45(\mathrm{~m}, 2 \mathrm{H}), 6.54(\mathrm{~d}, J=2.0 \mathrm{~Hz}, 1 \mathrm{H}), 6.72(\mathrm{t}, J=2.0 \mathrm{~Hz}, 1 \mathrm{H})$, $7.09(\mathrm{~d}, J=8.4 \mathrm{~Hz}, 1 \mathrm{H}), 7.31-7.46(\mathrm{~m}, 15 \mathrm{H}), 7.84(\mathrm{~d}, J=8.4 \mathrm{~Hz}, 1 \mathrm{H}) \mathrm{ppm} ;{ }^{13} \mathrm{C} \mathrm{NMR}\left(\mathrm{CDCl}_{3}\right.$, $100 \mathrm{MHz}) \delta 21.55,40.76,55.49,55.56,69.75,69.95,98.89,99.58,103.93,104.75,108.56,111.99$, $120.90,122.10,122.65,122.94,127.18,127.18,127.38,127.38,128.03,128.03,128.08,128.08$, $128.48,128.48,128.50,128.57,129.47,129.47,131.54,131.78,132.10,132.32,134.01,135.79$, 136.01, 136.22, 144.86, 159.22, 160.38, 161.52, 163.17, 182.48, 183.62 ppm; HRMS $\left(\mathrm{M}+\mathrm{H}^{+}\right)$calcd. for $\mathrm{C}_{45} \mathrm{H}_{39} \mathrm{~N}_{2} \mathrm{O}_{8} \mathrm{~S}$ 767.2427, found 767.2414; IR (KBr) 3433, 3113, 2937, 2874, 1634, 1599, 1499, $1450,1265,1170,1029,746,667,585 \mathrm{~cm}^{-1}$.

(1'-Tosyl-1'H-1,3'-bipyrrole-2,2'-diyl)bis((4-hydroxy-2-methoxyphenyl)methanone) (16). To a solution of $15(1.00 \mathrm{~g}, 1.30 \mathrm{mmol})$ in a $3: 1$ mixture of MeOH/EtOAc $(10 \mathrm{~mL})$ was added $\mathrm{Pd} / \mathrm{C}$ ( $0.54 \mathrm{~g}, 0.13 \mathrm{mmol}$, purity: $5 \%$ ) under $1 \mathrm{~atm} \mathrm{H}_{2}$. The mixture was stirred for about $12 \mathrm{~h}$ at room temperature. The suspension was filtered and the filtrate was washed with acetone $(100 \mathrm{~mL})$. The combined organic layers were concentrated in vacuum and the residue was purified by flash column chromatography (20\% acetone/petroleum ether, $\left.R_{\mathrm{f}}=0.3\right)$ to give $16(0.65 \mathrm{~g}, 85 \%)$ as a gray solid. mp 157.3-160.3 ${ }^{\circ} \mathrm{C} ;{ }^{1} \mathrm{H}$ NMR (400 MHz, $\left.\mathrm{CDCl}_{3}\right) \delta 2.31(\mathrm{~s}, 3 \mathrm{H}), 3.35(\mathrm{~s}, 3 \mathrm{H}), 3.38(\mathrm{~s}, 3 \mathrm{H}), 5.90$ $(\mathrm{s}, 1 \mathrm{H}), 5.99(\mathrm{~d}, J=8.4 \mathrm{~Hz}, 1 \mathrm{H}), 6.05(\mathrm{~s}, 1 \mathrm{H}), 6.20(\mathrm{~d}, J=8.0 \mathrm{~Hz}, 1 \mathrm{H}), 6.24(\mathrm{~s}, 1 \mathrm{H}), 6.39(\mathrm{~d}, J=2.4 \mathrm{~Hz}$, $1 \mathrm{H}), 6.42(\mathrm{~d}, J=2.8 \mathrm{~Hz}, 1 \mathrm{H}), 6.74(\mathrm{~s}, 1 \mathrm{H}), 6.94(\mathrm{~d}, J=8.0 \mathrm{~Hz}, 1 \mathrm{H}), 7.20-7.24(\mathrm{~m}, 3 \mathrm{H}), 7.49$ $(\mathrm{d}, J=3.2 \mathrm{~Hz}, 1 \mathrm{H}), 7.85(\mathrm{~d}, J=7.6 \mathrm{~Hz}, 2 \mathrm{H}), 8.29($ br s, $1 \mathrm{H}), 8.88$ (br s, $1 \mathrm{H}) \mathrm{ppm} ;{ }^{13} \mathrm{C} \mathrm{NMR}$ (acetone- $\left.d_{6}, 100 \mathrm{MHz}\right) \delta 21.52,55.70,55.79,99.45,100.04,106.99,107.75,109.35,112.76,120.50$, $122.35,122.46,123.34,128.81,128.81,130.01,130.46,130.46,131.23,132.07,132.20,134.03$, 134.68, 137.20, 146.06, 160.09, 161.31, 162.12, 163.86, 183.31, 183.35 ppm; HRMS $\left(\mathrm{M}+\mathrm{Na}^{+}\right)$calcd. for $\mathrm{C}_{31} \mathrm{H}_{26} \mathrm{~N}_{2} \mathrm{NaO}_{8} \mathrm{~S}$ 609.1308, found 609.1313; IR (KBr) 3422, 2934, 2853, 1606, 1466, 1436, 1313, $1268,1174,936,671 \mathrm{~cm}^{-1}$.

1'H-1,3'-Bipyrrole-2,2'-diylbis((4-hydroxy-2-methoxyphenyl)methanone) (17). To a solution of 16 $(100 \mathrm{mg}, 0.17 \mathrm{mmol})$ in a $1: 1 \mathrm{mixture}$ of $\mathrm{MeOH} / \mathrm{THF}(5 \mathrm{~mL})$ was added $\mathrm{KOH}(39 \mathrm{mg}, 0.69 \mathrm{mmol})$ at room temperature. After being stirred for $2 \mathrm{~h}$, the mixture was adjusted to $\mathrm{pH} 7.0$ with $0.5 \mathrm{~N} \mathrm{HCl}$ and extracted with EtOAc $(10 \mathrm{~mL} \times 3)$. The combined organic layers were dried over anhydrous sodium sulfate, filtered and concentrated in vacuum. The residue was purified by flash column chromatography (50\% EtOAc/petroleum ether, $\left.R_{\mathrm{f}}=0.3\right)$ to give $17(66 \mathrm{mg}, 90 \%)$ as a brown solid. $\mathrm{mp}$ 83.0-85.7 ${ }^{\circ} \mathrm{C}$; ${ }^{1} \mathrm{H}$ NMR (400 MHz, $\left.\mathrm{CD}_{3} \mathrm{OD}\right) \delta 3.55$ (s, 3H), $3.66(\mathrm{~s}, 3 \mathrm{H}), 6.00(\mathrm{t}, J=2.4 \mathrm{~Hz}, 1 \mathrm{H}), 6.09$ $(\mathrm{dd}, J=8.4,2.0 \mathrm{~Hz}, 1 \mathrm{H}), 6.17(\mathrm{~d}, J=2.0 \mathrm{~Hz}, 1 \mathrm{H}), 6.22(\mathrm{~d}, J=2.0 \mathrm{~Hz}, 1 \mathrm{H}), 6.33(\mathrm{dd}, J=8.4,2.0 \mathrm{~Hz}$, $1 \mathrm{H}), 6.36(\mathrm{dd}, J=4.0,2.0 \mathrm{~Hz}, 1 \mathrm{H}), 6.41(\mathrm{~d}, J=2.0 \mathrm{~Hz}, 1 \mathrm{H}), 6.83(\mathrm{~s}, 1 \mathrm{H}), 6.99(\mathrm{~d}, J=8.4 \mathrm{~Hz}, 1 \mathrm{H}), 7.02$ $(\mathrm{t}, J=1.6 \mathrm{~Hz}, 1 \mathrm{H}), 7.04(\mathrm{~d}, J=8.4 \mathrm{~Hz}, 1 \mathrm{H}) \mathrm{ppm} ;{ }^{13} \mathrm{C} \mathrm{NMR}\left(\mathrm{CD}_{3} \mathrm{OD}, 100 \mathrm{MHz}\right) \delta 55.69,55.85,99.75$, 
$100.10,106.98,107.78,109.96,110.64,120.78,121.46,124.03,124.43,127.17,132.42,132.57$, 133.67, 133.84, 133.96, 160.55, 161.11, 162.41, 162.56, 185.53, 185.61 ppm; HRMS (M + $\left.\mathrm{H}^{+}\right)$calcd. for $\mathrm{C}_{24} \mathrm{H}_{21} \mathrm{~N}_{2} \mathrm{O}_{6} 433.1400$, found 433.1379; IR (KBr) 3293, 2938, 1697, 1610, 1465, 1407, 1308, 1269 , $1201,1163,1121,1031,959,868,748 \mathrm{~cm}^{-1}$.

(4,4',5,5'-Tetrachloro-1'H-1,3'-bipyrrole-2,2'-diyl)bis((5-chloro-4-hydroxy-2-methoxyphenyl) methanone) (18). To a solution of 17 (20 mg, $0.05 \mathrm{mmol})$ in dry $\mathrm{MeCN}(2 \mathrm{~mL})$ at room temperature was gradually added NCS (37 mg, $0.28 \mathrm{mmol}$ ). After being stirred for about $6 \mathrm{~h}$ at room temperature, the mixture was quenched with water $(15 \mathrm{~mL})$ and extracted with EtOAc $(15 \mathrm{~mL} \times 3)$. The combined organic layers were dried over anhydrous sodium sulfate, filtered, and concentrated in vacuum. The residue was purified by flash column chromatography $\left(33 \%\right.$ EtOAc/petroleum ether, $\left.R_{\mathrm{f}}=0.2\right)$ to give $\mathbf{1 8}$ (11 mg, 40\%) as a yellow solid. mp $102.7-104.7{ }^{\circ} \mathrm{C} ;{ }^{1} \mathrm{H}$ NMR (400 MHz, acetone- $\left.d_{6}\right) \delta 3.65(\mathrm{~s}, 3 \mathrm{H})$, $3.71(\mathrm{~s}, 3 \mathrm{H}), 6.52(\mathrm{~s}, 1 \mathrm{H}), 6.55(\mathrm{~s}, 1 \mathrm{H}), 6.71(\mathrm{~s}, 1 \mathrm{H}), 7.10(\mathrm{~s}, 1 \mathrm{H}), 7.23(\mathrm{~s}, 1 \mathrm{H}) \mathrm{ppm} ;{ }^{13} \mathrm{C} \mathrm{NMR}$ $\left(\mathrm{CD}_{3} \mathrm{OD}+\mathrm{CDCl}_{3}, 100 \mathrm{MHz}\right) \delta 55.99,56.03,100.22,100.86,110.21,111.77,111.83,112.37,119.31$, $120.11,120.80$, 120.86, 124.20, 124.960, 125.98, 130.88, 131.42, 132.46, 157.01, 157.51, 158.39, 159.10, 181.27, 181.86 ppm; HRMS $\left(\mathrm{M}+\mathrm{H}^{+}\right)$calcd. for $\mathrm{C}_{24} \mathrm{H}_{15} \mathrm{Cl}_{6} \mathrm{~N}_{2} \mathrm{O}_{6} 636.9061$, found 636.9073; IR (KBr) 3441, 3230, 3130, 2936, 2855, 1723, 1628, 1602, 1403, 1298, 1271, 1215, 1037, 994, $745,666 \mathrm{~cm}^{-1}$.

(4,4',5,5'-Tetrachloro-1'H-1,3'-bipyrrole-2,2'-diyl)bis((5-chloro-2,4-dihydroxyphenyl)methanone) (19). To a solution of $18(14 \mathrm{mg}, 0.02 \mathrm{mmol})$ in dry $\mathrm{CH}_{2} \mathrm{Cl}_{2}(4 \mathrm{~mL})$ was slowly added a solution of $\mathrm{BBr}_{3}$ $(19 \mathrm{mg}, 0.08 \mathrm{mmol})$ in dry $\mathrm{CH}_{2} \mathrm{Cl}_{2}(1 \mathrm{~mL})$ via a syringe under $\mathrm{N}_{2}$ at $-78{ }^{\circ} \mathrm{C}$. After being stirred for $0.5 \mathrm{~h}$, the mixture was quenched by addition of water $(10 \mathrm{~mL})$ and extracted with $\mathrm{CH}_{2} \mathrm{Cl}_{2}(10 \mathrm{~mL} \times 3)$. The combined organic layers were dried over anhydrous sodium sulfate, filtered, and concentrated in vacuum. The residue was purified by flash column chromatography $(25 \% \mathrm{EtOAc/petroleum} \mathrm{ether,}$ $\left.R_{\mathrm{f}}=0.3\right)$ to give $19(11 \mathrm{mg}, 85 \%)$ as a pale brown solid. mp 145.7-147.7 ${ }^{\circ} \mathrm{C} ;{ }^{1} \mathrm{H} \mathrm{NMR}(400 \mathrm{MHz}$, $\left.\mathrm{CD}_{3} \mathrm{OD}\right) \delta 6.27(\mathrm{~s}, 1 \mathrm{H}), 6.32(\mathrm{~s}, 1 \mathrm{H}), 7.31(\mathrm{~s}, 1 \mathrm{H}), 7.41(\mathrm{~s}, 1 \mathrm{H}), 7.96(\mathrm{~s}, 1 \mathrm{H}) \mathrm{ppm} ;{ }^{13} \mathrm{C} \mathrm{NMR}\left(\mathrm{CD}_{3} \mathrm{OD}\right.$, $100 \mathrm{MHz}) \delta 101.49,105.13,105.25,110.00,112.90,113.27,114.67,119.42,120.24,123.00,123.87$, 125.98, 130.91, 132.64, 132.66, 133.99, 134.07, 163.85, 164.48, 165.02, 184.46, 185.64 ppm; HRMS $\left(\mathrm{M}+\mathrm{Na}^{+}\right)$calcd. for $\mathrm{C}_{22} \mathrm{H}_{10} \mathrm{Cl}_{6} \mathrm{~N}_{2} \mathrm{NaO}_{6}$ 630.8568, found 630.8581; IR (KBr) 3425, 2961, 2924, 2854, 1654, 1622, 1414, 1384, 1358, 1258, 1024, $800 \mathrm{~cm}^{-1}$. HPLC purity, 95.4\% (Flow rate: $1.0 \mathrm{~mL} / \mathrm{min}$; Column: Phenomenex C6-phenyl, $5 \mu \mathrm{m}, 150 \times 4.6 \mathrm{~mm}$; Wavelength: UV $254 \mathrm{~nm}$; Temperature: $25{ }^{\circ} \mathrm{C}$; Mobile phase: $\left.\mathrm{MeOH}: \mathrm{H}_{2} \mathrm{O}=80: 20 ; t_{\mathrm{R}}=5.1 \mathrm{~min}\right)$.

(1'-Tosyl-1'H-1,3'-bipyrrole-2,2'-diyl)bis(((2-methoxy-4-hydroxytrifluoromethanesulfonate)phenyl) methanone) (20). To a solution of $16(0.50 \mathrm{~g}, 0.85 \mathrm{mmol})$ in dry $\mathrm{MeCN}(10 \mathrm{~mL})$ at $-30{ }^{\circ} \mathrm{C}$ under $\mathrm{N}_{2}$ was slowly added DIEA $(0.44 \mathrm{~g}, 3.4 \mathrm{mmol})$. After being stirred for $5 \mathrm{~min}, \mathrm{Tf}_{2} \mathrm{O}(0.72 \mathrm{~g}, 2.60 \mathrm{mmol})$ was added slowly via a syringe. The mixture was stirred for about $3 \mathrm{~h}$ at room temperature and quenched with water $(10 \mathrm{~mL})$ and extracted with EtOAc $(10 \mathrm{~mL} \times 3)$. The combined organic layers were dried over anhydrous sodium sulfate, filtered and concentrated in vacuum. The residue was purified by flash column chromatography (15\% EtOAc/petroleum ether, $\left.R_{\mathrm{f}}=0.3\right)$ to give $20(0.62 \mathrm{~g}$, $86 \%$ ) as a pale brown solid. mp $116.3-120.0{ }^{\circ} \mathrm{C}$; ${ }^{1} \mathrm{H}$ NMR $\left(400 \mathrm{MHz}, \mathrm{CDCl}_{3}\right) \delta 2.46(\mathrm{~s}, 3 \mathrm{H}), 3.71$ $(\mathrm{s}, 3 \mathrm{H}), 3.79(\mathrm{~s}, 3 \mathrm{H}), 5.90(\mathrm{t}, J=2.8 \mathrm{~Hz}, 1 \mathrm{H}), 6.31(\mathrm{~d}, J=2.8 \mathrm{~Hz}, 1 \mathrm{H}), 6.38(\mathrm{~d}, J=3.2 \mathrm{~Hz}, 1 \mathrm{H}), 6.53$ $(\mathrm{d}, J=1.6 \mathrm{~Hz}, 1 \mathrm{H}), 6.63(\mathrm{dd}, J=8.4,1.6 \mathrm{~Hz}, 1 \mathrm{H}), 6.70(\mathrm{~s}, 1 \mathrm{H}), 6.80(\mathrm{~s}, 1 \mathrm{H}), 6.83(\mathrm{~d}, J=8.4 \mathrm{~Hz}$, 
1H), $7.22(\mathrm{~d}, J=8.4 \mathrm{~Hz}, 1 \mathrm{H}), 7.39(\mathrm{~d}, J=8.4 \mathrm{~Hz}, 3 \mathrm{H}), 7.67(\mathrm{~d}, J=3.6 \mathrm{~Hz}, 1 \mathrm{H}), 7.99(\mathrm{~d}, J=8.0 \mathrm{~Hz}$, 2H) ppm; ${ }^{13} \mathrm{C} \mathrm{NMR}\left(\mathrm{CDCl}_{3}, 100 \mathrm{MHz}\right) \delta 21.59,56.01,56.10,104.81,105.22,109.65,111.29,112.18$, $112.23,117.08,120.28,123.86,126.14,127.57,128.07,128.46,128.46,128.97,129.68,129.68$, $130.45,131.78,132.18,132.70,134.11,135.64,145.44,150.99,151.83,158.38,159.05,181.57$, 181.98 ppm; HRMS $\left(\mathrm{M}+\mathrm{H}^{+}\right)$calcd. for $\mathrm{C}_{33} \mathrm{H}_{25} \mathrm{~F}_{6} \mathrm{~N}_{2} \mathrm{O}_{12} \mathrm{~S}_{3}$ 851.0474, found 851.0480; IR (KBr) 3444, $3121,2950,2871,1642,1600,1493,1426,1269,1243,1141,948,827,581 \mathrm{~cm}^{-1}$.

(4,4',5,5'-Tetrachloro-1'-tosyl-1'H-1,3'-bipyrrole-2,2'-diyl)bis(((2-methoxy-4-hydroxytrifluorometh anesulfonate)phenyl)methanone) (21). To a solution of $20(0.50 \mathrm{~g}, 0.59 \mathrm{mmol})$ in dry DMF $(10 \mathrm{~mL})$ at room temperature was gradually added NCS $(0.51 \mathrm{~g}, 3.8 \mathrm{mmol})$. After being stirred for about $3 \mathrm{~h}$ at room temperature, the mixture was quenched with water $(15 \mathrm{~mL})$, and extracted with EtOAc $(15 \mathrm{~mL} \times 3)$. The combined organic layers were dried over anhydrous sodium sulfate, filtered and concentrated in vacuum. The residue was purified by flash column chromatography (12\% EtOAc/ petroleum ether, $\left.R_{\mathrm{f}}=0.2\right)$ to give $21(0.20 \mathrm{~g}, 35 \%)$ as a yellow solid. mp 81.7-83.3 ${ }^{\circ} \mathrm{C} ;{ }^{1} \mathrm{H}$ NMR $\left(400 \mathrm{MHz}, \mathrm{CD}_{3} \mathrm{OD}\right) \delta 2.49(\mathrm{~s}, 3 \mathrm{H}), 3.50(\mathrm{~s}, 3 \mathrm{H}), 3.61(\mathrm{~s}, 3 \mathrm{H}), 6.41(\mathrm{~s}, 1 \mathrm{H}), 6.57(\mathrm{~d}, J=8.0 \mathrm{~Hz}, 1 \mathrm{H}), 6.82$ $(\mathrm{d}, J=2.0 \mathrm{~Hz}, 1 \mathrm{H}), 6.90(\mathrm{~d}, J=2.0 \mathrm{~Hz}, 1 \mathrm{H}), 6.95(\mathrm{dd}, J=8.8,2.4 \mathrm{~Hz}, 1 \mathrm{H}), 7.32(\mathrm{~d}, J=8.4 \mathrm{~Hz}, 1 \mathrm{H})$, $7.51(\mathrm{~d}, J=12.0 \mathrm{~Hz}, 2 \mathrm{H}), 7.64(\mathrm{~d}, J=8.4 \mathrm{~Hz}, 1 \mathrm{H}), 7.92(\mathrm{~d}, J=8.4 \mathrm{~Hz}, 2 \mathrm{H}) \mathrm{ppm} ;{ }^{13} \mathrm{C} \mathrm{NMR}\left(\mathrm{CDCl}_{3}\right.$, $100 \mathrm{MHz}) \delta 21.61,55.90,56.13,104.61,105.00,112.01,112.54,113.03,113.61,116.93,119.59$, $120.12,120.80,125.09,127.11,128.01,128.40,128.40,129.32,129.94,129.94,131.06,131.30$, 132.63, 132.86, 133.68, 146.57, 151.94, 152.94, 158.53, 159.68, 180.21, 181.56 ppm; HRMS (M + $\left.\mathrm{H}^{+}\right)$ calcd. for $\mathrm{C}_{33} \mathrm{H}_{21} \mathrm{Cl}_{4} \mathrm{~F}_{6} \mathrm{~N}_{2} \mathrm{O}_{12} \mathrm{~S}_{3}$ 986.8915, found 986.8926; IR (KBr) 3446, 2923, 2853, 1653, 1603, $1491,1428,1270,1216,1140,996,950,831,585 \mathrm{~cm}^{-1}$.

(4,4',5,5'-Tetrachloro-1'-tosyl-1'H-1,3'-bipyrrole-2,2'-diyl)bis((2-hydroxy-4-hydroxytrifluorometha nesulfonate)phenyl)methanone) (22). To a solution of 21 (37 mg, $0.03 \mathrm{mmol})$ in dry $\mathrm{CH}_{2} \mathrm{Cl}_{2}(5 \mathrm{~mL})$ was slowly added a solution of $\mathrm{BBr}_{3}(56 \mathrm{mg}, 0.22 \mathrm{mmol})$ in dry $\mathrm{CH}_{2} \mathrm{Cl}_{2}(1 \mathrm{~mL})$ via a syringe under $\mathrm{N}_{2}$ at $-78{ }^{\circ} \mathrm{C}$. After being stirred for $0.5 \mathrm{~h}$, the mixture was quenched by addition of water $(10 \mathrm{~mL})$, and extracted with $\mathrm{CH}_{2} \mathrm{Cl}_{2}(10 \mathrm{~mL} \times 3)$. The combined organic layers were dried over anhydrous sodium sulfate, filtered and concentrated in vacuum. The residue was purified by flash column chromatography $\left(10 \%\right.$ EtOAc/petroleum ether, $\left.R_{\mathrm{f}}=0.3\right)$ to give $22(28 \mathrm{mg}, 78 \%)$ as a yellow solid. $\mathrm{mp} 71.3-73.0^{\circ} \mathrm{C}$; ${ }^{1} \mathrm{H}$ NMR (400 MHz, CD $\left.3 \mathrm{OD}\right) \delta 2.48(\mathrm{~s}, 3 \mathrm{H}), 6.41(\mathrm{~s}, 1 \mathrm{H}), 6.72-6.95(\mathrm{~m}, 4 \mathrm{H}), 7.35(\mathrm{~d}, J=8.0 \mathrm{~Hz}, 2 \mathrm{H})$, $7.50(\mathrm{~d}, J=8.8 \mathrm{~Hz}, 2 \mathrm{H}), 7.79(\mathrm{~d}, J=8.0 \mathrm{~Hz}, 2 \mathrm{H}), 11.28(\mathrm{br} \mathrm{s}, 1 \mathrm{H}) \mathrm{ppm} ;{ }^{13} \mathrm{C} \mathrm{NMR}\left(\mathrm{CDCl}_{3}, 100 \mathrm{MHz}\right)$ $\delta 21.76,110.86,111.12,111.12,111.12,112.21,112.40,112.87,113.93,116.93,116.94,118.33$, $118.35,120.15,122.32,125.44,128.30,128.30,130.18,130.18,132.90,134.18,135.40,135.42$, $135.43,147.32,154.40,163.51,163.78,186.18,188.56$ ppm; HRMS $\left(\mathrm{M}+\mathrm{H}^{+}\right)$calcd. for $\mathrm{C}_{31} \mathrm{H}_{17} \mathrm{Cl}_{4} \mathrm{~F}_{6} \mathrm{~N}_{2} \mathrm{O}_{12} \mathrm{~S}_{3}$ 958.8602, found 958.8610; IR (KBr) 3445, 3134, 2920, 2851, 1742, 1631, 1598, $1430,1385,1430,1216,1140,970,842,583 \mathrm{~cm}^{-1}$.

(4,4',5,5'-Tetrachloro-1'H-1,3'-bipyrrole-2,2'-diyl)bis(((2-hydroxy-4-hydroxytrifluoromethanesulfonate) phenyl)methanone) (23). To a solution of $22(165 \mathrm{mg}, 0.17 \mathrm{mmol})$ in a 1:1 mixture of $\mathrm{MeOH} / \mathrm{THF}$ $(3 \mathrm{~mL})$ was added $\mathrm{KOH}(39 \mathrm{mg}, 0.69 \mathrm{mmol})$ at room temperature. After being stirred for $15 \mathrm{~min}$, the mixture was adjusted to $\mathrm{pH} 7.0$ with $0.5 \mathrm{~N} \mathrm{HCl}$ and extracted with EtOAc $(10 \mathrm{~mL} \times 3)$. The combined organic layers were dried over anhydrous sodium sulfate, filtered, and concentrated in vacuum. The residue was purified by flash column chromatography $\left(33 \% \mathrm{EtOAc/petroleum} \mathrm{ether,} R_{\mathrm{f}}=0.3\right)$ to give 
23 (125 mg, 90.6\%) as a light yellow solid. mp 65.7-67.7 ${ }^{\circ} \mathrm{C} ;{ }^{1} \mathrm{H}$ NMR $\left(400 \mathrm{MHz}, \mathrm{CDCl}_{3}\right) \delta 6.17$ (s, 1H), $6.53(\mathrm{dd}, J=7.6,2.0 \mathrm{~Hz}, 1 \mathrm{H}), 6.81(\mathrm{dd}, J=8.8,2.0 \mathrm{~Hz}, 1 \mathrm{H}), 6.87$ (d, $J=2.4 \mathrm{~Hz}, 1 \mathrm{H}), 6.93$ (d, $J=2.4 \mathrm{~Hz}, 1 \mathrm{H}), 7.40$ (br s, 1H), 7.57 (d, $J=8.8 \mathrm{~Hz}, 1 \mathrm{H}), 9.61$ (br s, 1H), 10.67 (s, 1H), 11.49 (s, $1 \mathrm{H}) \mathrm{ppm} ;{ }^{13} \mathrm{C} \mathrm{NMR}\left(\mathrm{CDCl}_{3}, 100 \mathrm{MHz}\right) \delta 109.34,111.21,111.33,111.61,112.44,115.90,117.01$, $118.50,118.60,118.89,122.60,123.61,124.41,124.92,132.11,135.49,151.32,153.72,154.72$, 161.95, 162.77, 164.22, 184.70, 186.90 ppm; HRMS $\left(\mathrm{M}+\mathrm{H}^{+}\right)$calcd. for $\mathrm{C}_{24} \mathrm{H}_{11} \mathrm{Cl}_{4} \mathrm{~F}_{6} \mathrm{~N}_{2} \mathrm{O}_{10} \mathrm{~S}_{2}$ 804.8513, found 804.8529; IR (KBr) 3380, 3264, 1627, 1597, 1497, 1429, 1217, 1139, 1107, 970, 942, $605 \mathrm{~cm}^{-1}$. HPLC purity, 96.0\% (Flow rate: $1.0 \mathrm{~mL} / \mathrm{min}$; Column: Phenomenex C6-phenyl, $5 \mu \mathrm{m}$, $150 \times 4.6 \mathrm{~mm}$; Wavelength: UV $254 \mathrm{~nm}$; Temperature: $25^{\circ} \mathrm{C}$; Mobile phase: $\mathrm{MeOH}: \mathrm{H}_{2} \mathrm{O}=75: 25$; $\left.t_{\mathrm{R}}=17.9 \mathrm{~min}\right)$.

(4,4',5,5'-Tetrachloro-1'H-1,3'-bipyrrole-2,2'-diyl)bis((2,4-dihydroxyphenyl)methanone) (24). To a solution of $23(5.0 \mathrm{mg}, 0.006 \mathrm{mmol})$ in DMSO $(1 \mathrm{~mL})$ was added a solution of $\mathrm{KF}(1.1 \mathrm{mg}$, $0.018 \mathrm{mmol})$ in water $(0.1 \mathrm{~mL})$ at room temperature. After being stirred for about $3 \mathrm{~h}$, the mixture was added with water $(5 \mathrm{~mL})$ and extracted with EtOAc $(5 \mathrm{~mL} \times 3)$. The combined organic layers were dried over anhydrous sodium sulfate, filtered, and concentrated in vacuum. The residue was purified by flash column chromatography (40\% EtOAc/petroleum ether, $\left.R_{\mathrm{f}}=0.3\right)$ to give $\mathbf{2 4}(2.6 \mathrm{mg}, 75 \%)$ as a pale yellow solid. mp 103.3-105.3 ${ }^{\circ} \mathrm{C}$; ${ }^{1} \mathrm{H}$ NMR (400 MHz, acetone- $\left.d_{6}\right) \delta 6.10(\mathrm{~s}, 1 \mathrm{H}), 6.19$ (dd, $J=8.8,2.4 \mathrm{~Hz}, 1 \mathrm{H}), 6.22-6.23(\mathrm{~m}, 2 \mathrm{H}), 6.28(\mathrm{~d}, J=8.0 \mathrm{~Hz}, 1 \mathrm{H}), 7.62(\mathrm{~d}, J=8.8 \mathrm{~Hz}, 1 \mathrm{H}), 8.09$ (br s, 1H), 12.03 (br s, 1H) ppm; ${ }^{13} \mathrm{C} \mathrm{NMR}\left(\mathrm{CDCl}_{3}, 100 \mathrm{MHz}\right) \delta 103.19,103.49,107.73,108.14$, $108.30,108.35,109.60,111.44,113.20,113.77,114.26,115.07,120.82,123.89,126.11,134.16$, 137.03, 162.89, 165.67, 166.61, 167.02, 185.94 ppm; HRMS $\left(\mathrm{M}+\mathrm{H}^{+}\right)$calcd. for $\mathrm{C}_{22} \mathrm{H}_{13} \mathrm{Cl}_{4} \mathrm{~N}_{2} \mathrm{O}_{6}$ 540.9528, found 540.9536; IR (KBr) 3400, 3282, 2958, 2922, 2851, 1626, 1596, 1447, 1333, 1266, 1177, 978, $796 \mathrm{~cm}^{-1}$. HPLC purity, 98.2\% (Flow rate: $1.0 \mathrm{~mL} / \mathrm{min}$; Column: Waters C8, $5 \mu \mathrm{m}$, $150 \times 4.6 \mathrm{~mm}$; Wavelength: UV $254 \mathrm{~nm}$; Temperature: $25^{\circ} \mathrm{C}$; Mobile phase: $\mathrm{MeOH}: \mathrm{H}_{2} \mathrm{O}=65: 35$; $\left.t_{\mathrm{R}}=6.2 \mathrm{~min}\right)$.

(2-((tert-Butyldimethylsilyloxy)methyl)-1'-tosyl-1'H-1,3'-bipyrrol-2'-yl)(2-methoxy-4-(trifluoromethyl) phenyl)methanol (25). To a solution of 1-bromo-2-methoxy-4-(trifluoromethyl)benzene (69.0 mg, $0.27 \mathrm{mmol})$ in dry THF $(4 \mathrm{~mL})$ at $-78{ }^{\circ} \mathrm{C}$ under $\mathrm{N}_{2}$ was slowly added $N$-BuLi $(0.11 \mathrm{~mL}, 2.5 \mathrm{M}$ in $\mathrm{N}$-pentane, $0.27 \mathrm{mmol})$. After being stirred for $30 \mathrm{~min}$, a solution of $8(50 \mathrm{mg}, 0.11 \mathrm{mmol})$ in dry THF $(1 \mathrm{~mL})$ was added slowly via a syringe. The mixture was stirred for about $2 \mathrm{~h}$ and quenched by addition of a saturated aqueous $\mathrm{NH}_{4} \mathrm{Cl}(15 \mathrm{~mL})$ solution, and extracted with EtOAc $(10 \mathrm{~mL} \times 3)$. The combined organic layers were dried over anhydrous sodium sulfate, filtered and concentrated in vacuum. The residue was purified by flash column chromatography (15\% EtOAc/petroleum ether, $\left.R_{\mathrm{f}}=0.2\right)$ to give $25(56 \mathrm{mg}, 81 \%)$ as a pale brown solid. mp $34.7-36.7{ }^{\circ} \mathrm{C} ;{ }^{1} \mathrm{H} \mathrm{NMR}(400 \mathrm{MHz}$, $\left.\mathrm{CDCl}_{3}\right) \delta 0.001(\mathrm{~s}, 3 \mathrm{H}), 0.07(\mathrm{~s}, 3 \mathrm{H}), 0.83(\mathrm{~s}, 9 \mathrm{H}), 2.41(\mathrm{~s}, 3 \mathrm{H}), 2.94(\mathrm{~d}, J=4.0 \mathrm{~Hz}, 1 \mathrm{H}), 3.73(\mathrm{~s}$, $3 \mathrm{H}), 4.43(\mathrm{~d}, J=12.0 \mathrm{~Hz}, 1 \mathrm{H}), 4.75(\mathrm{~d}, J=12.0 \mathrm{~Hz}, 1 \mathrm{H}), 5.81-5.84(\mathrm{~m}, 2 \mathrm{H}), 6.10(\mathrm{t}, J=3.2 \mathrm{~Hz}$, $1 \mathrm{H}), 6.34(\mathrm{~d}, J=3.6 \mathrm{~Hz}, 1 \mathrm{H}), 6.66(\mathrm{dd}, J=3.6,2.0 \mathrm{~Hz}, 1 \mathrm{H}), 6.99(\mathrm{~s}, 1 \mathrm{H}), 7.18(\mathrm{~d}, J=8.0 \mathrm{~Hz}, 1 \mathrm{H})$, $7.24(\mathrm{~d}, J=3.6 \mathrm{~Hz}, 1 \mathrm{H}), 7.30(\mathrm{~d}, J=8.0 \mathrm{~Hz}, 2 \mathrm{H}), 7.55(\mathrm{~d}, J=8.0 \mathrm{~Hz}, 1 \mathrm{H}), 7.85(\mathrm{~d}, J=8.4 \mathrm{~Hz}$, 2H) ppm; ${ }^{13} \mathrm{C} \mathrm{NMR}\left(\mathrm{CDCl}_{3}, 100 \mathrm{MHz}\right) \delta-5.71,-5.67,18.53,21.56,25.92,25.92,25.92,53.27$, $55.53,62.79,106.87,106.91,108.05,108.43,111.37,117.21,117.25,121.56,123.91,126.96,127.01$, $127.35,128.40,129.44,129.87,134.75,134.76,135.81,136.29,145.17,156.02$ ppm; HRMS 
$\left(\mathrm{M}+\mathrm{Na}^{+}\right.$) calcd. for $\mathrm{C}_{31} \mathrm{H}_{37} \mathrm{~F}_{3} \mathrm{~N}_{2} \mathrm{NaO}_{5} \mathrm{SSi}$ 657.2042, found 657.2040; IR (KBr) 3383, 3146, 2956, 2929, 2857, 1734, 1594, 1465, 1415, 1377, 1329, 1241, 1175, 1123, 1032, 841, 778, $670 \mathrm{~cm}^{-1}$.

(2-((tert-Butyldimethylsilyloxy)methyl)-1'-tosyl-1'H-1,3'-bipyrrol-2'-yl)(2-methoxy-4-(trifluoromethyl) phenyl)methanone (26). To a solution of $25(463 \mathrm{mg}, 0.73 \mathrm{mmol})$ in dry DMSO (10 $\mathrm{mL})$ was added IBX (408 mg, $1.46 \mathrm{mmol}$ ) at room temperature. The mixture was allowed to warm up to $50{ }^{\circ} \mathrm{C}$ and stir additionally for about $3.5 \mathrm{~h}$. The mixture was quenched with water $(15 \mathrm{~mL})$ and extracted with EtOAc $(10 \mathrm{~mL} \times 3)$. The combined organic layers were dried over anhydrous sodium sulfate, filtered, and concentrated in vacuum. The residue was purified by flash column chromatography (15\% EtOAc/ petroleum ether, $\left.R_{\mathrm{f}}=0.2\right)$ to give $26(403 \mathrm{mg}, 85 \%)$ as a pale brown solid. mp $38.0-40.3{ }^{\circ} \mathrm{C} ;{ }^{1} \mathrm{H}$ NMR $\left(400 \mathrm{MHz}, \mathrm{CDCl}_{3}\right) \delta-0.006(\mathrm{~s}, 6 \mathrm{H}), 0.85(\mathrm{~s}, 9 \mathrm{H}), 2.40(\mathrm{~s}, 3 \mathrm{H}), 3.82$ (s, 3H), $4.68(\mathrm{~s}, 3 \mathrm{H}), 6.23$ (dd, $J=4.0,2.4 \mathrm{~Hz}, 1 \mathrm{H}), 6.33(\mathrm{~d}, J=3.6 \mathrm{~Hz}, 1 \mathrm{H}), 6.64(\mathrm{dd}, J=4.0,1.6 \mathrm{~Hz}, 1 \mathrm{H}), 7.09(\mathrm{t}, J=2.0 \mathrm{~Hz}, 1 \mathrm{H})$, $7.21-7.23(\mathrm{~m}, 2 \mathrm{H}), 7.28(\mathrm{~d}, J=8.0 \mathrm{~Hz}, 2 \mathrm{H}), 7.40$ (d, $J=8.0 \mathrm{~Hz}, 1 \mathrm{H}), 7.85(\mathrm{~d}, J=8.4 \mathrm{~Hz}, 2 \mathrm{H}) \mathrm{ppm}$; ${ }^{13} \mathrm{C} \mathrm{NMR}\left(\mathrm{CDCl}_{3}, 100 \mathrm{MHz}\right) \delta-5.65,-5.65,18.42,21.55,25.65,25.86,25.86,53.48,55.86,108.06$, $108.09,109.50,111.33,116.83,116.87,121.33,123.91,127.00,127.66,129.27,129.38,129.77$, 131.85, 132.60, 132.93, 132.99, 133.48, 136.64, 144.82, 157.04, 182.61 ppm; HRMS $\left(\mathrm{M}+\mathrm{Na}^{+}\right)$calcd. for $\mathrm{C}_{31} \mathrm{H}_{35} \mathrm{~F}_{3} \mathrm{~N}_{2} \mathrm{NaO}_{5} \mathrm{SSi}$ 655.1886, found 655.1893; IR (KBr) 3145, 2955, 2929, 2856, 1737, 1647, $1598,1499,1463,1411,1376,1328,1245,1176,1130,1077,894,838,670 \mathrm{~cm}^{-1}$.

(2-(Hydroxymethyl)-1'-tosyl-1'H-1,3'-bipyrrol-2'-yl)(2-methoxy-4-(trifluoromethyl)phenyl)methanone (27). To a solution of 26 (400 mg, $0.63 \mathrm{mmol})$ in dry THF (10 mL) was added TBAF (495 mg, $1.90 \mathrm{mmol}$ ) at room temperature. After being stirred for about $5 \mathrm{~h}$ at room temperature, the mixture was quenched with water $(10 \mathrm{~mL})$ and extracted with EtOAc $(10 \mathrm{~mL} \times 3)$. The combined organic layers were dried over anhydrous sodium sulfate, filtered, and concentrated in vacuum. The residue was purified by flash column chromatography $\left(20 \%\right.$ EtOAc/petroleum ether, $\left.R_{\mathrm{f}}=0.3\right)$ to give 27 (290 mg, 87\%) as a light yellow solid. mp 53.3-56.0 ${ }^{\circ} \mathrm{C} ;{ }^{1} \mathrm{H}$ NMR (400 $\left.\mathrm{MHz}, \mathrm{CDCl}_{3}\right) \delta 2.35$ (s, 3H), $2.98(\mathrm{t}, J=6.4 \mathrm{~Hz}, 1 \mathrm{H}), 3.76(\mathrm{~s}, 3 \mathrm{H}), 4.54(\mathrm{~d}, J=6.8 \mathrm{~Hz}, 2 \mathrm{H}), 6.24(\mathrm{t}, J=3.6 \mathrm{~Hz}, 1 \mathrm{H}), 6.34(\mathrm{~d}$, $J=6.8 \mathrm{~Hz}, 1 \mathrm{H}), 6.61(\mathrm{dd}, J=3.6,1.2 \mathrm{~Hz}, 1 \mathrm{H}), 7.04(\mathrm{~s}, 1 \mathrm{H}), 7.14(\mathrm{~s}, 1 \mathrm{H}), 7.22(\mathrm{~d}, J=3.6 \mathrm{~Hz}, 1 \mathrm{H})$, $7.26-7.30(\mathrm{~m}, 3 \mathrm{H}), 7.38(\mathrm{~d}, J=8.0 \mathrm{~Hz}, 1 \mathrm{H}), 7.84(\mathrm{~d}, J=8.4 \mathrm{~Hz}, 2 \mathrm{H}) \mathrm{ppm} ;{ }^{13} \mathrm{C} \mathrm{NMR}\left(\mathrm{CDCl}_{3}\right.$, $100 \mathrm{MHz}) \delta 21.56,53.09,55.92,108.14,108.17,110.27,110.92,116.94,116.97,122.31,124.59$, $127.16,128.46,128.55,129.15,130.11,132.03,132.68,132.89,133.00,133.74,135.81,145.48$, 157.03, 183.56 ppm; HRMS $\left(\mathrm{M}+\mathrm{Na}^{+}\right)$calcd. for $\mathrm{C}_{25} \mathrm{H}_{21} \mathrm{~F}_{3} \mathrm{~N}_{2} \mathrm{NaO}_{5} \mathrm{~S}$ 541.1021, found 541.1027; IR (KBr) 3425, 3119, 2956, 2925, 1642, 1596, 1500, 1460, 1411, 1328, 1175, 1133, 1078, 893, $673,602 \mathrm{~cm}^{-1}$.

2'-(2-Methoxy-4-(trifluoromethyl)benzoyl)-1'-tosyl-1'H-1,3'-bipyrrole-2-carbaldehyde (28). To a solution of 27 (286 mg, $0.55 \mathrm{mmol})$ in dry DMSO (10 mL) was added IBX (309 $\mathrm{mg}, 1.10 \mathrm{mmol})$ at room temperature. After being stirred for about $3.5 \mathrm{~h}$, the mixture was quenched with water $(15 \mathrm{~mL})$ and extracted with EtOAc $(10 \mathrm{~mL} \times 3)$. The combined organic layers were dried over anhydrous sodium sulfate, filtered, and concentrated in vacuum. The residue was purified by flash column chromatography (20\% EtOAc/petroleum ether, $\left.R_{\mathrm{f}}=0.3\right)$ to give $28(242 \mathrm{mg}, 85 \%)$ as a light brown solid. mp 114.3-117.0 ${ }^{\circ} \mathrm{C} ;{ }^{1} \mathrm{H} \mathrm{NMR}\left(400 \mathrm{MHz}, \mathrm{CDCl}_{3}\right) \delta 2.43(\mathrm{~s}, 3 \mathrm{H}), 3.80(\mathrm{~s}, 3 \mathrm{H}), 6.29$ (t, $J=3.2 \mathrm{~Hz}$, 1H), $6.48(\mathrm{~d}, J=3.6 \mathrm{~Hz}, 1 \mathrm{H}), 6.63(\mathrm{~d}, J=2.4 \mathrm{~Hz}, 1 \mathrm{H}), 7.03(\mathrm{~s}, 1 \mathrm{H}), 7.13(\mathrm{~s}, 1 \mathrm{H}), 7.24(\mathrm{~d}, J=7.6 \mathrm{~Hz}$, $1 \mathrm{H}), 7.35(\mathrm{~d}, J=8.0 \mathrm{~Hz}, 2 \mathrm{H}), 7.46(\mathrm{~d}, J=7.6 \mathrm{~Hz}, 1 \mathrm{H}), 7.69(\mathrm{~d}, J=3.2 \mathrm{~Hz}, 1 \mathrm{H}), 7.89$ (d, $J=8.4 \mathrm{~Hz}$, 
2H), $9.70(\mathrm{~s}, 1 \mathrm{H}) \mathrm{ppm} ;{ }^{13} \mathrm{C} \mathrm{NMR}\left(\mathrm{CDCl}_{3}, 100 \mathrm{MHz}\right) \delta 21.63,55.89,108.12,108.15,110.55,111.54$, $116.88,116.92$, 123.99, 125.49, 127.53, 127.90, 127.90, 129.62, 130.08, 130.08, 132.34, 132.63, 132.81, 133.15, 134.75, 138.21, 146.08, 177.23, 182.75 ppm; HRMS $\left(\mathrm{M}+\mathrm{Na}^{+}\right)$calcd. for $\mathrm{C}_{25} \mathrm{H}_{19} \mathrm{~F}_{3} \mathrm{~N}_{2} \mathrm{NaO}_{5} \mathrm{~S}$ 539.0864, found 539.0856; IR (KBr) 3433, 3141, 3089, 2927, 2855, 1679, 1641, $1562,1408,1327,1173,1128,1023,901,812,670 \mathrm{~cm}^{-1}$.

(2-(Hydroxy(2-methoxy-4-(trifluoromethyl)phenyl)methyl)-1'-tosyl-1'H-1,3'-bipyrrol-2'-yl)(2-methoxy4-(trifluoromethyl)phenyl)methanone (29). To a solution of 1-bromo-2-methoxy-4-(trifluoromethyl)benzene (200 mg, $0.78 \mathrm{mmol})$ in dry THF $(8 \mathrm{~mL})$ at $-78{ }^{\circ} \mathrm{C}$ under $\mathrm{N}_{2}$ was slowly added $N$-BuLi $(0.31 \mathrm{~mL}$, $2.5 \mathrm{M}$ in $\mathrm{N}$-pentane, $0.78 \mathrm{mmol})$. After being stirred for $30 \mathrm{~min}$, a solution of 28 (200 $\mathrm{mg}, 0.39 \mathrm{mmol})$ in dry THF $(2 \mathrm{~mL})$ was added slowly via a syringe. After the mixture was stirred at $-78^{\circ} \mathrm{C}$ for $2 \mathrm{~h}$, the reaction was quenched by addition of a saturated aqueous solution of $\mathrm{NH}_{4} \mathrm{Cl}(15 \mathrm{~mL})$ and extracted with EtOAc $(10 \mathrm{~mL} \times 3)$. The combined organic layers were dried over anhydrous sodium sulfate, filtered and concentrated in vacuum. The residue was purified by flash column chromatography (15\% EtOAc/petroleum ether, $\left.R_{\mathrm{f}}=0.2\right)$ to give $29(150 \mathrm{mg}, 56 \%)$ as a light yellow solid, 29A (42 mg, 15\%) as a light yellow solid and recovered 28 (48 mg, 24\%). mp for 29, 85.1-86.3 ${ }^{\circ} \mathrm{C}$; ${ }^{1} \mathrm{H}$ NMR (400 MHz, $\left.\mathrm{CDCl}_{3}\right) \delta 2.44$ (s, 3H), 3.59 (br s, 3H), 3.84 (s, 3H), 4.12 (br s, 1H), 5.77 (br s, $1 \mathrm{H}), 6.17-6.32(\mathrm{~m}, 3 \mathrm{H}), 6.49$ (br s, 1H), 6.70 (br s, 1H), 6.83 (d, $J=7.6 \mathrm{~Hz}, 1 \mathrm{H}), 7.13$ (br s, 1H), 7.21 (br s, 1H), 7.35-7.37 (m, 4H), $7.42(\mathrm{~d}, J=2.8 \mathrm{~Hz}, 1 \mathrm{H}), 7.92(\mathrm{~d}, J=8.0 \mathrm{~Hz}, 2 \mathrm{H}) \mathrm{ppm} ;{ }^{13} \mathrm{C}$ NMR $\left(\mathrm{CDCl}_{3}, 100 \mathrm{MHz}\right) \delta 21.67,55.75,55.88,67.96,105.60,105.64,108.13,108.03,111.28,116.78$, $116.78,116.78,120.85,120.85,124.97,126.20,127.10,127.30,127.63,127.63,129.14,129.14$, $129.98,129.98,132.50,132.56,133.21,133.45,135.92,145.38,155.48,157.01,180.50$ ppm; HRMS $\left(\mathrm{M}+\mathrm{Na}^{+}\right)$calcd. for $\mathrm{C}_{33} \mathrm{H}_{26} \mathrm{~F}_{6} \mathrm{~N}_{2} \mathrm{NaO}_{6} \mathrm{~S} 715.1313$, found 715.1287; IR (KBr) 3444, 3137, 2923, 1668, $1562,1447,1361,1180,1014,752,668 \mathrm{~cm}^{-1}$.

(2-(Hydroxy(2-methoxy-4-(trifluoromethyl)phenyl)methyl)-1'-tosyl-1'H-1,3'-bipyrrol-2'-yl)bis (2-methoxy-4-(trifluoromethyl)phenyl)methanol (29A). mp 103.7-104.5 ${ }^{\circ} \mathrm{C} ;{ }^{1} \mathrm{H}$ NMR (600 MHz, $\left.\mathrm{CDCl}_{3}\right) \delta 2.46(\mathrm{~s}, 3 \mathrm{H}), 3.30(\mathrm{~s}, 3 \mathrm{H}), 3.64(\mathrm{~s}, 3 \mathrm{H}), 3.74(\mathrm{br} \mathrm{s}, 3 \mathrm{H}), 5.30-5.42(\mathrm{~m}, 5 \mathrm{H}), 5.78(\mathrm{~d}, J=8.4 \mathrm{~Hz}$, $1 \mathrm{H}), 6.47(\mathrm{~d}, J=8.4 \mathrm{~Hz}, 2 \mathrm{H}), 6.75(\mathrm{~s}, 1 \mathrm{H}), 6.81(\mathrm{~d}, J=7.2 \mathrm{~Hz}, 1 \mathrm{H}), 7.03-7.15(\mathrm{~m}, 8 \mathrm{H}), 7.29(\mathrm{~d}$, $J=7.2 \mathrm{~Hz}, 1 \mathrm{H}), 7.34(\mathrm{~d}, J=7.2 \mathrm{~Hz}, 2 \mathrm{H}), 7.87(\mathrm{~d}, J=7.2 \mathrm{~Hz}, 2 \mathrm{H}) \mathrm{ppm} ;{ }^{13} \mathrm{C} \mathrm{NMR}\left(\mathrm{CDCl}_{3}\right.$, $150 \mathrm{MHz}) \delta 21.66,55.08,55.37,56.00,61.74,105.41,106.67,108.30,109.09,111.52,112.15$, $116.80,116.89,117.42,119.68,122.76,122.90,123.30,124.57,124.71,125.11,125.28,125.78$, $127.82,128.68,129.17,129.38,129.68,129.95,131.08,131.36,131.56,132.38,134.02,136.38$, 136.67, 144.93, 155.51, 155.51, 156.10, 157.72 ppm; HRMS $\left(\mathrm{M}+\mathrm{Na}^{+}\right)$calcd. for $\mathrm{C}_{41} \mathrm{H}_{33} \mathrm{~F}_{9} \mathrm{~N}_{2} \mathrm{NaO}_{7} \mathrm{~S}$ 891.1762, found 891.1716; IR (KBr) 3408, 1587, 1503, 1461, 1415, 1378, 1331, 1239, 1175, 1123, $1082,1027,922,894,860,718,672,595 \mathrm{~cm}^{-1}$.

(1'-Tosyl-1'H-1,3'-bipyrrole-2,2'-diyl)bis((2-methoxy-4-(trifluoromethyl)phenyl)methanone) (30). To a solution of $29(800 \mathrm{mg}, 1.16 \mathrm{mmol})$ in dry DMSO $(20 \mathrm{~mL})$ was gradually added IBX $(810 \mathrm{mg}$, $2.89 \mathrm{mmol})$ at room temperature. After being stirred for about $1 \mathrm{~h}$, the mixture was quenched with water $(30 \mathrm{~mL})$ and extracted with EtOAc $(15 \mathrm{~mL} \times 3)$. The combined organic layers were dried over anhydrous sodium sulfate, filtered, and concentrated in vacuum. The residue was purified by flash column chromatography (20\% EtOAc/petroleum ether, $\left.R_{\mathrm{f}}=0.2\right)$ to give $\mathbf{3 0}(670 \mathrm{mg}, 84 \%)$ as a light yellow solid. mp 81.3-83.3 ${ }^{\circ} \mathrm{C}$; ${ }^{1} \mathrm{H}$ NMR (400 MHz, $\left.\mathrm{CDCl}_{3}\right) \delta 2.45$ (s, 3H), 3.78 (s, 3H), 3.80 (s, 
$3 \mathrm{H}), 5.89(\mathrm{t}, J=2.8 \mathrm{~Hz}, 1 \mathrm{H}), 6.26(\mathrm{~d}, J=2.8 \mathrm{~Hz}, 1 \mathrm{H}), 6.41(\mathrm{~d}, J=3.6 \mathrm{~Hz}, 1 \mathrm{H}), 6.74(\mathrm{~s}, 1 \mathrm{H}), 6.85$ (s, $1 \mathrm{H}), 6.98(\mathrm{~d}, J=8.0 \mathrm{~Hz}, 1 \mathrm{H}), 7.12-7.19(\mathrm{~m}, 3 \mathrm{H}), 7.37$ (d, $J=7.6 \mathrm{~Hz}, 3 \mathrm{H}), 7.65(\mathrm{~d}, J=3.2 \mathrm{~Hz}$, $1 \mathrm{H}), 7.96(\mathrm{~d}, J=8.0 \mathrm{~Hz}, 2 \mathrm{H}) \mathrm{ppm} ;{ }^{13} \mathrm{C} \mathrm{NMR}\left(\mathrm{CDCl}_{3}, 100 \mathrm{MHz}\right) \delta 21.68,55.81,55.85,107.74$, $108.17,109.43,111.60,116.43,116.63,123.90,125.74,128.13,128.36,128.36,129.29,129.66$, $129.66,130.63,131.01,131.61,132.13,132.77,133.06,133.83,134.05,134.15,135.56,145.37$, 145.37, 157.06, 157.69, 182.04, 183.06 ppm; HRMS $\left(\mathrm{M}+\mathrm{H}^{+}\right)$calcd. for $\mathrm{C}_{33} \mathrm{H}_{25} \mathrm{~F}_{6} \mathrm{~N}_{2} \mathrm{O}_{6} \mathrm{~S}$ 691.1338, found 691.1336; IR (KBr) 3633, 3433, 3148, 2940, 1650, 1586, 1461, 1413, 1330, 1175, 1129, $1028,671 \mathrm{~cm}^{-1}$.

1'H-1,3'-Bipyrrole-2,2'-diylbis((2-methoxy-4-(trifluoromethyl)phenyl)methanone) (31). To a solution of $30(670 \mathrm{mg}, 0.97 \mathrm{mmol})$ in a $1: 1$ mixture of $\mathrm{MeOH} / \mathrm{THF}(10 \mathrm{~mL})$ was added $\mathrm{KOH}(218 \mathrm{mg}$, $3.88 \mathrm{mmol}$ ) at room temperature. After being stirred for $15 \mathrm{~min}$, the mixture was adjusted to $\mathrm{pH} 7.0$ with $0.5 \mathrm{~N} \mathrm{HCl}$ and extracted with EtOAc $(10 \mathrm{~mL} \times 3)$. The combined organic layers were dried over anhydrous sodium sulfate, filtered, and concentrated in vacuum. The residue was purified by flash column chromatography (33\% EtOAc/petroleum ether, $\left.R_{\mathrm{f}}=0.3\right)$ to give $31(494 \mathrm{mg}, 95 \%)$ as a light yellow solid. mp 75.0-77.0 ${ }^{\circ} \mathrm{C} ;{ }^{1} \mathrm{H}$ NMR (400 $\left.\mathrm{MHz} \mathrm{CDCl}_{3}\right) \delta 3.76(\mathrm{~s}, 3 \mathrm{H}), 3.84(\mathrm{~s}, 3 \mathrm{H}), 5.84$ $(\mathrm{t}, J=4.0 \mathrm{~Hz}, 1 \mathrm{H}), 6.29-6.32(\mathrm{~m}, 2 \mathrm{H}), 6.65(\mathrm{~s}, 1 \mathrm{H}), 6.87(\mathrm{~s}, 1 \mathrm{H}), 6.95(\mathrm{~d}, J=7.6 \mathrm{~Hz}, 1 \mathrm{H}), 7.11$ (t, $J=3.2 \mathrm{~Hz}, 1 \mathrm{H}), 7.14(\mathrm{~s}, 1 \mathrm{H}), 7.19-7.21(\mathrm{~m}, 2 \mathrm{H}), 7.25-7.26(\mathrm{~m}, 1 \mathrm{H}), 9.51$ (br s, 1H) ppm; ${ }^{13} \mathrm{C} \mathrm{NMR}\left(\mathrm{CDCl}_{3}, 100 \mathrm{MHz}\right) \delta 55.61,55.85,107.31,108.26,109.08,110.68,116.64,116.87,116.91$, $123.92,124.21,125.88,128.88,129.38,131.32,131.63,131.75,132.26,132.50,132.58,132.65$, 132.92, 156.39, 157.11, 182.18, 182.49 ppm; HRMS $\left(\mathrm{M}+\mathrm{H}^{+}\right)$calcd. for $\mathrm{C}_{26} \mathrm{H}_{19} \mathrm{~F}_{6} \mathrm{~N}_{2} \mathrm{O}_{4} 537.1249$, found 537.1238; IR (KBr) 3295, 2943, 1636, 1462, 1413, 1331, 1126, 1076, 928, 829, $742 \mathrm{~cm}^{-1}$.

1'H-1,3'-Bipyrrole-2,2'-diylbis((2-hydroxy-4-(trifluoromethyl)phenyl)methanone) (32). To a solution of $31(100 \mathrm{mg}, 0.19 \mathrm{mmol})$ in dry $\mathrm{CH}_{2} \mathrm{Cl}_{2}(5 \mathrm{~mL})$ was slowly added a solution of $\mathrm{BBr}_{3}(233 \mathrm{mg}$, $0.93 \mathrm{mmol})$ in dry $\mathrm{CH}_{2} \mathrm{Cl}_{2}(1 \mathrm{~mL})$ via a syringe under $\mathrm{N}_{2}$ at $-78{ }^{\circ} \mathrm{C}$. After being stirred for $0.5 \mathrm{~h}$, the mixture was quenched by addition of water $(10 \mathrm{~mL})$ and extracted with $\mathrm{CH}_{2} \mathrm{Cl}_{2}(10 \mathrm{~mL} \times 3)$. The combined organic layers were dried over anhydrous sodium sulfate, filtered, and concentrated in vacuum. The residue was purified by flash column chromatography $(30 \%$ EtOAc/petroleum ether, $\left.R_{\mathrm{f}}=0.3\right)$ to give $32(78 \mathrm{mg}, 82 \%)$ as a yellow solid. mp $148.0-149.0{ }^{\circ} \mathrm{C} ;{ }^{1} \mathrm{H} \mathrm{NMR}\left(400 \mathrm{MHz}, \mathrm{CDCl}_{3}\right)$ $\delta 6.26(\mathrm{dd}, J=4.0,2.8 \mathrm{~Hz}, 1 \mathrm{H}), 6.39(\mathrm{~s}, 1 \mathrm{H}), 6.69(\mathrm{~d}, J=8.0 \mathrm{~Hz}, 1 \mathrm{H}), 6.75(\mathrm{dd}, J=4.0,1.2 \mathrm{~Hz}$, $1 \mathrm{H}), 6.98(\mathrm{t}, J=2.0 \mathrm{~Hz}, 1 \mathrm{H}), 7.01(\mathrm{~d}, J=8.4 \mathrm{~Hz}, 1 \mathrm{H}), 7.03(\mathrm{~s}, 1 \mathrm{H}), 7.21(\mathrm{~d}, J=5.6 \mathrm{~Hz}, 2 \mathrm{H})$, $7.37(\mathrm{~d}, J=8.0 \mathrm{~Hz}, 1 \mathrm{H}), 8.40(\mathrm{~d}, J=8.0 \mathrm{~Hz}, 1 \mathrm{H}), 9.46($ br s, $1 \mathrm{H}), 10.85($ br s, $1 \mathrm{H}), 11.42$ (br s, 1H) ppm; ${ }^{13} \mathrm{C} \mathrm{NMR}\left(\mathrm{CDCl}_{3}, 100 \mathrm{MHz}\right) \delta 109.89,111.00,114.80,114.83,114.98,115.02$, $115.42,115.45,121.36,121.80,123.28,124.15,124.47,129.99,130.53,130.92,132.19,132.41$, 136.17, 136.59, 161.01, 162.11, 186.42, 187.09 ppm; HRMS $\left(\mathrm{M}+\mathrm{H}^{+}\right)$calcd. for $\mathrm{C}_{24} \mathrm{H}_{15} \mathrm{~F}_{6} \mathrm{~N}_{2} \mathrm{O}_{4}$ 509.0936, found 509.0934; IR (KBr) 3334, 3148, 3080, 1636, 1591, 1562, 1412, 1337, 1231, 1130, $1068,944,875,786,748,605 \mathrm{~cm}^{-1}$.

(4,4',5,5'-Tetrachloro-1'H-1,3'-bipyrrole-2,2'-diyl)bis((2-hydroxy-4-(trifluoromethyl)phenyl)methanone) (33). To a solution of $\mathbf{3 2}(50 \mathrm{mg}, 0.10 \mathrm{mmol})$ in dry $\mathrm{MeCN}(10 \mathrm{~mL})$ at room temperature was stepwise added NCS (72 mg, $0.54 \mathrm{mmol}$ ). After being stirred for about $3.5 \mathrm{~h}$ at room temperature, the mixture was quenched with water $(10 \mathrm{~mL})$ and extracted with EtOAc $(10 \mathrm{~mL} \times 3)$. The combined organic layers were dried over anhydrous sodium sulfate, filtered, and concentrated in vacuum. The residue 
was purified by flash column chromatography $\left(12 \%\right.$ EtOAc/petroleum ether, $\left.R_{\mathrm{f}}=0.2\right)$ to give 33 (12 mg, 20\%) as a yellow solid. mp 70.7-72.3 ${ }^{\circ} \mathrm{C} ;{ }^{1} \mathrm{H}$ NMR $\left(400 \mathrm{MHz}, \mathrm{CDCl}_{3}\right) \delta 6.74(\mathrm{~d}, J=8.3 \mathrm{~Hz}$, $1 \mathrm{H}), 6.80(\mathrm{~s}, 1 \mathrm{H}), 7.17(\mathrm{~d}, J=8.3 \mathrm{~Hz}, 1 \mathrm{H}), 7.20(\mathrm{~s}, 1 \mathrm{H}), 7.31(\mathrm{~s}, 1 \mathrm{H}), 7.58(\mathrm{~d}, J=8.2 \mathrm{~Hz}, 1 \mathrm{H}), 7.77(\mathrm{~d}$, $J=8.3 \mathrm{~Hz}, 1 \mathrm{H}), 10.06(\mathrm{~s}, 1 \mathrm{H}), 10.22(\mathrm{~s}, 1 \mathrm{H}), 11.17(\mathrm{~s}, 1 \mathrm{H}) \mathrm{ppm} ;{ }^{13} \mathrm{C} \mathrm{NMR}\left(\mathrm{CDCl}_{3}, 100 \mathrm{MHz}\right) \delta \mathrm{ppm}$ $110.94,113.57,114.93,115.14,115.54,115.94,120.82,121.07,121.21,121.49,123.41,123.45$, $125.00,128.25,130.59,132.36,136.70,137.03,137.20,137.53,160.53,162.37,184.81,186.10$; HRMS $\left(\mathrm{M}+\mathrm{H}^{+}\right)$calcd. for $\mathrm{C}_{24} \mathrm{H}_{11} \mathrm{Cl}_{4} \mathrm{~F}_{6} \mathrm{~N}_{2} \mathrm{O}_{4}$ 644.9372, found 644.9372; IR (KBr) 3789, 3661, 3577, 2917, 2847, 1726, 1636, 1601, 1489, 1407, 1332, 1218, 1133, 946, $832 \mathrm{~cm}^{-1}$. HPLC purity, 97.2\% (Flow rate: $1.0 \mathrm{~mL} / \mathrm{min}$; Column: Waters C8, $5 \mu \mathrm{m}, 150 \times 4.6 \mathrm{~mm}$; Wavelength: UV $254 \mathrm{~nm}$; Temperature: $25{ }^{\circ} \mathrm{C}$; Mobile phase: $\mathrm{MeOH}: \mathrm{H}_{2} \mathrm{O}=68: 32 ; t_{\mathrm{R}}=9.2 \mathrm{~min}$ ).

\subsection{In Vitro Antibacterial Assays}

A panel of multiple resistance Gram-positive and Gram-negative pathogens listed in Figures 2 and 3 was used to evaluate the antibacterial activity of marinopyrrole derivatives with vancomycin as a positive control. Except for those marked with WHO, all pathogens were isolated between 2008 and 2010 in hospitals located in Beijing, Guangzhou, Sichuan, Shandong, and Jiangsu Province. The minimum inhibitory concentration (MIC) was determined as the lowest concentration of antibiotic that inhibited visible bacterial growth by the guidelines of the Clinical and Laboratory Standards Institute [25]. The concentrations of a marinopyrrole derivative are 128, 64, 32, 16, 8, 4, 2, 1, 0.5, 0.25, $0.125,0.06,0.03,0.015$, and $0.008 \mu \mathrm{g} / \mathrm{mL}$.

\section{Conclusions}

This article describes optimization of general synthetic routes to access novel symmetrical marinopyrrole derivatives and evaluation of their in vitro antibacterial activity against a panel of Gram-positive pathogens including MRSA. The efforts were focused on improving antibacterial potency with chemistry focused on synthetic strategy and route optimization. The optimized methods paved the way towards diverse sets of both symmetrical and potentially non-symmetrical marinopyrroles. The new route circumvented the low yields due to the formation of byproduct oxazepine 5 encountered from our first total synthesis [12]. The parent compound, ( \pm )-marinopyrrole A, not only showed potent activity comparable to that of vancomycin against MRSA and MRSE, but also exhibited higher potency (64-128 fold) than vancomycin against moderately resistant VRE (Figure 2). SAR studies of derivatives have clearly demonstrated that the tetrachloro substituents on the pyrrole rings, hydroxyl groups in the ortho position and an electron-withdrawing group in the meta or para position on the phenyl rings are important for achieving potent antibacterial activity against the Gram-positive pathogens tested. Of particular interest, the best compound 33 showed 63-125 fold, eight-fold and four-fold more potent than vancomycin, in addition to 31 fold, four-fold and four-fold more potent than the parent marinopyrrole A (1), against MRSE, MSSA and MRSA, respectively (Figure 3). These results provide useful information for further optimization in the search for new-generation antibiotics against MRSA, MRSE and other pathogens. In summary, we have designed and optimized synthetic routes to access novel marinopyrrole derivatives. The SAR studies led to 33 - a compound with superior antibiotic activity to that of vancomycin against a broad spectrum of 
Gram-positive pathogens. Design and synthesis of novel non-symmetrical and symmetrical marinopyrroles are actively ongoing with four patent applications being filed. Their activity, selectivity, and ADME/tox data will be published in due course.

\section{Acknowledgments}

This work was supported by grants from the National Natural Science Foundation of China (20825207, 21021001 and 21132006), the National Science and Technology Major Project of China (2011ZX09401-304), and the National Basic Research Program of China (973 program, 2010CB833200) to Yong Qin, and partially supported by start-up funds from Moffitt Cancer Center to Rongshi Li. We thank Sichuan Industrial Institute of Antibiotics for evaluation of in vitro antibacterial activity of marinopyrrole derivatives. We are grateful to ChemAxon for the Software and Jian Wang from Shenyang Pharmaceutical University, for assistance in $\mathrm{p} K_{\mathrm{a}}$ and $\log p$ calculations.

\section{Conflicts of Interest}

The authors declare no conflicts of interest.

\section{References}

1. Grundmann, H.; Aires-de-Sousa, M.; Boyce, J.; Tiemersma, E. Emergence and resurgence of meticillin-resistant Staphylococcus aureus as a public-health threat. Lancet 2006, 368, 874-885.

2. Como-Sabetti, K.; Harriman, K.H.; Buck, J.M.; Glennen, A.; Boxrud, D.J.; Lynfield, R. Community-associated methicillin-resistant Staphylococcus aureus: Trends in case and isolate characteristics from six years of prospective surveillance. Public Health Rep. 2009, 124, 427-435.

3. Chambers, H.F.; Deleo, F.R. Waves of resistance: Staphylococcus aureus in the antibiotic era. Nat. Rev. Microbiol. 2009, 7, 629-641.

4. Deleo, F.R.; Otto, M.; Kreiswirth, B.N.; Chambers, H.F. Community-associated meticillin-resistant Staphylococcus aureus. Lancet 2010, 375, 1557-1568.

5. Lowy, F.D. Antimicrobial resistance: The example of Staphylococcus aureus. J. Clin. Investig. 2003, 111, 1265-1273.

6. Zhao, K.; Reiner, J.; Xie, W. FDA new drug approvals in 2000. Front. Biotechnol. Pharm. 2001, 2, 329-349.

7. Eisenstein, B.I. Lipopeptides, focusing on daptomycin, for the treatment of Gram-positive infections. Expert Opin. Investig. Drugs 2004, 13, 1159-1169.

8. FDA Approves Teflaro for Bacterial Infections. FDA News \& Events 2010, 10/29/2010. Available online: http://www.fda.gov/NewsEvents/Newsroom/PressAnnouncements/ucm231594.htm (accessed on 1 March 2012).

9. Butler, M.S.; Buss, A.D. Natural products-The future scaffolds for novel antibiotics? Biochem. Pharmacol. 2006, 71, 919-929.

10. Hughes, C.C.; Prieto-Davo, A.; Jensen, P.R.; Fenical, W. The marinopyrroles, antibiotics of an unprecedented structure class from a marine Streptomyces sp. Org. Lett. 2008, 10, 629-631. 
11. Hughes, C.C.; Kauffman, C.A.; Jensen, P.R.; Fenical, W. Structures, reactivities, and antibiotic properties of the marinopyrroles A-F. J. Org. Chem. 2010, 75, 3240-3250.

12. Cheng, C.; Pan, L.; Chen, Y.; Song, H.; Qin, Y.; Li, R. Total synthesis of ( \pm )-marinopyrrole A and its library as potential antibiotic and anticancer agents. J. Comb. Chem. 2010, 12, 541-547.

13. Kanakis, A.A.; Sarli, V. Total synthesis of $( \pm)$-marinopyrrole A via copper-mediated $N$-arylation. Org. Lett. 2010, 12, 4872-4875.

14. Nicolaou, K.C.; Simmons, N.L.; Chen, J.S.; Haste, N.M.; Nizet, V. Total synthesis and biological evaluation of marinopyrrole A and analogues. Tetrahedron Lett. 2011, 52, 2041-2043.

15. Liu, Y.; Haste, N.M.; Thienphrapa, W.; Nizet, V.; Hensler, M.; Li, R. Marinopyrrole derivatives as potential antibiotic agents against methicillin-resistant Staphylococcus aureus (I). Mar. Drugs 2012, 10, 953-962.

16. Pan, L.; Cheng, C.; Song, H. Optimization of synthetic method of marinopyrrole A derivatives. Chem. J. Chin. Univ. 2012, 33, 1476-1480.

17. Yamanaka, K.; Ryan, K.S.; Gulder, T.A.; Hughes, C.C.; Moore, B.S. Flavoenzyme-catalyzed atropo-selective $\mathrm{N}, \mathrm{C}$-bipyrrole homocoupling in marinopyrrole biosynthesis. J. Am. Chem. Soc. 2012, 134, 12434-12437.

18. Cheng, P.; Clive, D.L.; Fernandopulle, S.; Chen, Z. Racemic marinopyrrole B by total synthesis. Chem. Commun. (Camb.) 2013, 49, 558-560.

19. Clive, D.L.J.; Cheng, P. The marinopyrroles. Tetrahedron 2013, 69, 5067-5078.

20. Dixon, S.L.; Jurs, P.C. Estimation of $\mathrm{p} K_{\mathrm{a}}$ for organic oxyacids using calculated atomic charge. J. Comp. Chem. 1993, 14, 1460-1467.

21. Csizmadia, F.; Tsantili-Kakoulidou, A.; Panderi, I.; Darvas, F. Prediction of distribution coefficient from structure. 1. Estimation method. J. Pharm. Sci. 1997, 86, 865-871.

22. Liptak, M.D.; Gross, K.C.; Seybold, P.G.; Feldgus, S.; Shields, G.C. Absolute pK(a) determinations for substituted phenols. J. Am. Chem. Soc. 2002, 124, 6421-6427.

23. Kuhn, B.; Mohr, P.; Stahl, M. Intramolecular hydrogen bonding in medicinal chemistry. J. Med. Chem. 2010, 53, 2601-2611.

24. Lipinski, C.A.; Lombardo, F.; Dominy, B.W.; Feeney, P.J. Experimental and computational approaches to estimate solubility and permeability in drug discovery and development settings. Adv. Drug Del. Rev. 2001, 46, 3-26.

25. Clinical and Laboratory Standards Institute (CLSI). Performance Standards for Antimicrobial Susceptibility Testing; Seventeenth Informational Supplement M100-S17; Clinical and Laboratory Standards Institute: Wayne, PA, USA, 2007; Volume 27, pp. 110-114.

Samples Availability: Available from the authors.

(C) 2013 by the authors; licensee MDPI, Basel, Switzerland. This article is an open access article distributed under the terms and conditions of the Creative Commons Attribution license (http://creativecommons.org/licenses/by/3.0/). 